\title{
Twin Study of Early-Onset Major Depression Finds DNA Methylation Enrichment for Neurodevelopmental Genes
}

\author{
Roxann Roberson-Nay ${ }^{1,2}$, Aaron R. Wolen ${ }^{4}$, Dana M. Lapato ${ }^{2,4}$, Eva E. Lancaster ${ }^{2,4}$, \\ Bradley T. Webb ${ }^{1,2,4}$, Bradley Verhulst ${ }^{3}$, John M. Hettema ${ }^{1,2}$, Timothy P. York ${ }^{2,4}$
}

1. Virginia Commonwealth University, Department of Psychiatry, Richmond, VA.

2. Virginia Commonwealth University, Virginia Institute for Psychiatric and Behavioral Genetics, Richmond, VA.

3. Department of Psychology, Michigan State University, East Lansing, MI.

4. Virginia Commonwealth University, Department of Human and Molecular Genetics, Richmond, VA.

Correspondence: Roxann Roberson-Nay, Ph.D., Virginia Commonwealth University, Department of Psychiatry, Virginia Institute for Psychiatric and Behavioral Genetics, P.O. Box 980489, Richmond, VA 23298, Fax (804) 828-0245, email: roxann.robersonnay@vcuhealth.org. 


\begin{abstract}
Major depression (MD) is a debilitating mental health condition with peak prevalence occurring early in life. Genome-wide examination of DNA methylation (DNAm) offers an attractive complement to studies of allelic risk given it can reflect the combined influence of genes and environment. The current study used a co-twin control design to identify differentially and variably methylated regions of the genome that distinguish monozygotic $(\mathrm{MZ})$ twins with and without a lifetime history of early-onset MD. The sample included 150 Caucasian monozygotic twins (73\% female; Mage=17.52 $S D=1.28$ ) assessed during a developmental stage characterized by relatively distinct neurophysiological changes. All twins were generally healthy and currently free of medications with psychotropic effects. DNAm was measured in peripheral blood cells using the Infinium Human BeadChip 450K Array. MD associations were detected at 760 differentially and variably methylated probes/regions that mapped to 428 genes. Results indicated an association between early-onset MD and many genes and genomic regions involved in neural circuitry formation, projection, functioning, and plasticity. Gene enrichment analyses implicated genes related to neuron structures and neurodevelopmental processes including cell-cell adhesion genes (e.g., CDHs, PCDHAs, PCDHA1C/2C). Genes previously implicated in mood and psychiatric disorders as well as chronic stress (e.g., HDAC4, NRG1) also were identified. DNAm regions associated with MD where found to overlap genetic loci observed in the latest Psychiatric Genomics Consortium metaanalysis of depression. Understanding the time course of epigenetic influences during emerging adulthood may clarify developmental phases where genes modulate individual differences in MD risk.
\end{abstract}




\section{Introduction}

Major depression (MD) is highly prevalent, ranking second in the global burden of disease, with the overall lifetime risk estimated to be $16.2 \%$ in the general population ${ }^{1}$. MD is associated with increased mortality, particularly suicide ${ }^{1}$. Among adolescents, MD is associated with the greatest level of impairment of all psychiatric conditions, with $16 \%$ of females and $12 \%$ of males endorsing at least one major depressive episode (MDE) by age $18^{2}$. An early age of onset confers increased risk for negative socioemotional outcomes including recurrent $\mathrm{MDEs}^{3,4}$. Adolescence/young adulthood is characterized by neurophysiological changes (e.g., synaptic pruning, myelination) that significantly influence brain function and behavior, which may increase risk for MD and other psychiatric conditions ${ }^{5}$. Thus, understanding the genetic contributions to MD during this dynamic neurophysiological period where peak incidence is observed ${ }^{2,6-8}$ is critical to elucidating developmentally informed pathways to mood disorders.

Twin and family studies robustly demonstrate that genetic factors play a role in risk for MD, with heritability estimates of roughly $35 \%$ for MD and $45 \%$ for early-onset $M^{9}$. The largest meta-analysis of molecular genetic studies of MD recently identified 44 independent loci, underscoring the centrality of genetic factors in the etiology of $\mathrm{MD}^{10}$. Twin study variance component analyses also indicate a considerable contribution of unique environmental risk factors to $\mathrm{MD}^{11}$. Due to the substantial link between environmental hardship and onset of a $\operatorname{MDE}^{12,13}$, epigenetic mechanisms may, in part, mediate the influence of environmental stress and interact with genetic liability for MD over the lifespan ${ }^{14-16}$. Epigenetic mechanisms refer to DNA, chromatin, and RNA modifications that can influence the expression of genes but do not alter the underlying genetic sequence. Animal studies have been critical to demonstrating a causal association between early life environments, epigenetic alterations, and phenotypic outcomes. For example, the seminal work of Michael Meaney and his research team demonstrates the importance of maternal care in altering the expression of genes that regulate behavioral and neuroendocrine responses to stress as well as synaptic development in the rat hippocampus ${ }^{17-22}$. Indeed, a number of animal and 
human studies demonstrate lasting epigenetic alterations occurring in the genomes of cells including changes to post-mitotic neurons that integrate experience-dependent changes ${ }^{23}$. Thus, the timing of environmental stress plays an important role in subsequent epigenetic consequences, with early life stress paradigms in mice and humans demonstrating enduring changes in epigenetic profiles ${ }^{17,20,24-28}$.

A number of studies have utilized genome-wide platforms to determine DNA methylation (DNAm) differences between MD cases and controls. However, as much as $37 \%$ of methylation variance can be accounted for by genetic factors ${ }^{30}$ with recent studies indicating that common genetic variation (i.e., methylation quantitative trait loci $[m Q T L s]$ ) influence DNAm levels ${ }^{31-35}$. Most MD case-control studies of DNAm do not account for allelic variation which means genetic and environmental influences on DNAm cannot be disaggreagated. In contrast, the quasi-experimental design afforded by the co-twin control approach greatly improves on the unmatched casecontrol design (see Supplemental Figure 1). The use of monozygotic (MZ) twins removes the impact of unmeasured confounds such as genetic variation, uterine environment, age, sex, race, cohort effects, and exposure to many shared environmental events.

The current study utilitized the robust co-twin control method and a statistically powerful approach to detect differentially and variably methylated DNAm regions associated with MD in a sample of adolescent and emerging adult twins. Studying this developmental period offers a number of advantages over later life periods including fewer confounds to DNAm variability such as a history of prolonged or multiple psychiatric/medical comorbidities and medication usage as well as long-term nicotine use. Moreover, it eliminates the well-known epigenetic changes associated with aging ${ }^{36-38}$. The developmental window of young adulthood also is associated with moderate conservation of DNAm that is nonetheless responsive to environmental signals ${ }^{39}$, making it an ideal sensitive period for the study of MD.

\section{Methods}

\section{Participants}


One hundred sixty-six MZ twins (83 pairs) were selected from a larger sample of twins ( $N=430$ pairs) enrolled in a study examining risk factors for internalizing disorders in a general population sample of twins $(\mathrm{R} 01 \mathrm{MH} 101518)^{40}$. Twins were primarily recruited through the MidAtlantic Twin Registry (MATR), a population-based registry ${ }^{40,41}$. All participants (parents/minor children, adults) provided written informed consent/assent.

Of the 83 twin pairs initially identified as $M Z$ via the zygosity questionnaire, five pairs (6.3\%) were determined to be DZ pairs using DNA-based markers and were removed (for zygosity determination, see Supplemental). One or both twins from three additional pairs failed DNA-based quality control checks, reducing the final analyzed sample to $75 \mathrm{MZ}$ twin pairs (150 twins; see Table 1). All twins were raised together in the same home and were required to be free of psychotropic medications/medications with psychotropic effects at the time of study entry, although approximately $4.0 \%(n=6)$ endorsed a history of psychotropic medication use, slightly lower than the national average ${ }^{42}$. See full study exclusionary criteria in Supplement.

\section{Measures}

Major Depression. All twin pairs completed a psychiatric history based on an expanded version of the Composite International Diagnostic Interview (CIDI)-Short Form, which queried DSM-5 MD Criterion A and C (see Supplement for questions and diagnostic algorithm ${ }^{43}$. Current depressive symptoms also were assessed using the Short Mood and Feelings Questionniare (SMFQ), which is a 13-item questionnaire validated to measure depressive symptoms in adolescents and adults ${ }^{44}$.

\section{DNA Methylation Processing}

Detailed information concerning DNA extraction, methylation assessment, normalization, and quality control (QC) can be found in the Supplement.

\section{DNA Methylation Analysis}

Analytic Approach. Based on observations that the average correlation between probes on the $450 \mathrm{~K}$ microarray within approximately 250 base pairs (bp) is 0.83 and within $1 \mathrm{~kb}$ is $0.45^{45-}$ 
${ }^{47}$, several methods have been proposed to take advantage of this structure to identify consistent DNAm change across a contiguous region ${ }^{45,46,48,49}$. Current approaches quantify regional DNAm change either as a mean difference (differentially methylated region [DMR]) or as a difference in variance (variably methylated region [VMR]). Due to the sparse and highly clustered placement of features on the Illumina $450 \mathrm{~K}$ platform, a custom approach for defining DMRs and VMRs was developed for this study motivated by the algorithm proposed by Ong et al. ${ }^{45,50}$. They suggest both a regional and individual CpG probe approach run in tandem since approximately $25 \%$ of probes do not have a neighboring probe within $1 \mathrm{~kb}$. To this end, the single-probe analysis provided the raw materials for the regional approach adopted to identify and assess significance of DMRs and VMRs. Type I error rates were estimated from empirical $P$-values for all univariate statisitics (mean level and variance based tests) described below were calculated using a permutation approach. For $k=1,000$ reorderings, the outcome variable was resampled in a way that preserved the discordance/concordance pair status frequencies. The false discovery rate $(\text { FDR })^{51}$ was estimated from the distribution of these empirical $P$-values.

\section{Identifying Regional DNAm Change}

Differentially Methylated Regions. Potential DMRs were constructed using only those individual $\mathrm{CpG}$ probes associated with MD status resulting in a test statistic in the upper or lower $5^{\text {th }}$ percentile of all probes tested. Univariate tests were performed by fitting a linear mixed-effects model $^{52}$ separately for each probe by regressing the normalized DNAm probe intensity on MD status while adjusting NK cell proportion and inclusion of a random effect term to account for twin pair membership. NK cell proportion was the only estimated cell type nominally significantly different between MD cases and controls $(t=0.266, p=0.051)$, so it was included as a covariate to control for potential bias that might arise from DNAm differences due to changes in NK blood cell proportions rather than those attributable to DNAm changes associated with MD itself.

The structure of $M Z$ twin exposure groupings provided an opportunity to focus on DNAm associations that are unique to MD versus other experimental design features. The sample used 
for study was composed of three types of MZ twin pairs (i.e., discordant MD, concordant MD, concordant healthy) and resulted in number of potential statistical contrasts to be tested (Supplemental Table 1). Specific contrasts were simultaneously fit within the linear model to estimate the degree of association among two sets of comparisons: 1) the effect of interest (e.g., MD affected versus MD unaffected) and 2) extraneous associations not of interest. The latter set of contrasts, while of general interest, do not directly relate to MD and were filtered from downstream applications. For example, the comparison of DNAm levels where MD is expressed in both members (concordant MD) versus only a single member (discordant MD) may be associated with a unique DNAm profile (i.e., line 2 in Supplemental Table 1). Probes with test statistics in the $1^{\text {st }}$ and $99^{\text {th }}$ quantiles identified in any contrast not of interest were removed.

From the set of filtered CpG probes, a candidate DMR was defined as having at least 2 contiguous $\mathrm{CpGs}$ within $1 \mathrm{~kb}$. The strength of a DMR association was estimated by a test statistic reflecting the area of influence approximated by the trapezoidal rule where the height $(h)$ was the length in base pairs between two contiguous $\mathrm{CpGs}$ and $a$ and $b$ were the univariate test statistic for the contiguous CpGs. For DMRs with more than two CpGs, the area for each contiguous pairing was summed to represent the area under the curve (AUC) for the entire DMR. All probes in the DMR had the restriction of test statistics with the same sign. A positive test statistic indicated hypermethylation in cases versus controls while a negative test statistic indicated hypomethylation.

Variably Methylated Regions. A similar strategy was adopted to identify variably methylated regions (VMR). In this case, the test statistic calculated was the $F$-value comparing the variance of two samples applied to the filtered set of $\mathrm{CpG}$ probes. Again, only probes for the contrast of interest were considered $\left(10^{\text {th }} / 90^{\text {th }}\right.$ percentiles $)$ if they did not intersect with those from contrasts not of interest $\left(1^{\text {st }} / 99^{\text {th }}\right.$ percentiles $)$. VMRs were restricted to at least two contiguous probes within $1 \mathrm{~kb}$ whereby all probes had the restriction of either increasing or decreasing variability in cases versus controls. 
Significance Assessment of Regional Change. The statistical significance of DMR and VMR AUC estimates were assessed using a rank-based permutation method ${ }^{53}$. This nonparametric method estimates an FDR without relying on strong assumptions about the normality of the data. The $k=1,000$ permutations of univariate tests were used to estimate the expected order statistics. The FDR was calculated based on the observed versus expected null scores. Briefly, for a range of thresholds, regions are called significant if the value of the observed ordered test statistic minus the mean value from the permuted rank exceeds a given threshold. The number of falsely called regions is the median number of regions that exceed the lowest AUC value of regions called significant. The FDR is calculated as the ratio of the number of falsely called regions to the number of regions called significant. An implementation of the SAM algorithm is available as a $\mathrm{R}$ package $\mathrm{e}^{54}$ but was recoded to allow for flexibility in specifying models for the twin data and to trim extreme test statistics likely to be false positives before the calculation of the FDR.

\section{Functional and Regulatory Enrichment}

The distribution of significant CpG probes and regions identified to be differentially and variably methylated by MD status were examined separately across functional and regulatory annotations. CpG findings were mapped to known genes ${ }^{55}$ for enrichment of Gene Ontology classifications $^{56}$ using clusterProfiler ${ }^{57}$. Classification functons included biological processes, cellular components, and molecular function, in addition to KEGG pathways. Tests for nonrandom association of $\mathrm{CpG}$ island features and ChromHMM chromatin states were based on the AH5086 and AH46969 tracks from the AnnotationHub package ${ }^{58}$, respectively. CpG island shores were defined as being $2 \mathrm{~kb}$ regions flanking $\mathrm{CpG}$ islands while shelves were demarcated as $2 \mathrm{~kb}$ upstream or downsteam shore regions. A test of enrichment for each of these annotations was calculated by comparing the proportion of sequence from the intersection of significant CpG regions with the regions defined by the annotation feature. Bootstrap methods using 1,000 resamplings were used to estimate $95 \%$ confidence intervals. This observed overlap was 
compared to an empirical distribution of random samples of genome groups of the same size and structure drawn from the background set under consideration. Empirical P-values were calculated from 1,000 random reorderings of the data using standard methods ${ }^{59}$.

\section{PGC GWAS Enrichment}

A similar resampling method was performed to count the number of significant $\mathrm{CpG}$ regions that overlapped with the findings of a recent genome-wide association study (GWAS) meta-analysis conducted by the Psychiatric Genomics Consortium (PGC) group ${ }^{10}$. The depression phenotype in this meta-analysis was derived from a number of different methods including clinical interview, self-report, electronic medical record abstraction, and self-report of a lifetime diagnosis. This study identified 44 MD-associated loci across 18 chromosomes, which included genes enriched for targets of antidepressant medication. The non-random frequency of overlap between the significant $\mathrm{CpG}$ regions and the 44 independent PGC findings was assessed using bootstrap and permutation approaches from 1,000 data resamplings.

\section{Results}

\section{Sample Characteristics}

MZ twins meeting DSM-5 MD criteria at the probable or definite level self-reported higher depression symptom scores on the SMFQ and had higher rates of generalized anxiety disorder compared to MD unaffected twins $(t(1,146)=6.4, p<.001) ; \chi^{2}(1)=5.31, p=.04$, respectively; see Table 1). For those twins meeting DSM-5 criteria for at least one MDE, the mean age at onset was approximately 15 years, and the majority of twins $(\sim 85 \%)$ reported experiencing 3 or fewer MDEs in their lifetime. Most MD affected twins (82\%) reported five or more symptoms during their worst lifetime MDE. Subject age, sex, self-reported ethnicity, and combustible cigarette use did not differ by MD status.

\section{Differentially Methylated Probes and Regions}

From the set of 455,828 screened CpG probes, according to our definition, 50,990 background regions could be created, covering 59.9 megabases. After DMP tests, 3,995 
regions consisting of $28,600 \mathrm{CpG}$ probes could be considered candidate DMRs. Seventeen DMRs were identified as significantly associated with MD (all hypermethylated in MD cases) of which 15 mapped onto genes (FDR 9.9\%; see Table 2). The number of CpG probes in significant DMRs ranged from 3 to 7 (median=4). Individual probe testing (DMP) resulted in 59 hypomethylated and 77 hypermethylated CpG sites with respect to MD status (FDR 1\%; Supplemental Table 2). The combined set of $30.6 \mathrm{~kb}$ DNA sequence covered by significant DMR and DMP findings was found to have a nonrandom pattern of enrichment across ChromHMM annotations, specifically sites of strong transcription $(p=0.019)$, enhancers $(p=0.045)$, ZNF genes/repeats $(p=0.001)$, heterochromatin $(p=0.013)$ and weak repressed polycomb $(p=0.045)$ (Supplemental Figure 2) and CpG island relationships which included both north $(p=0.024)$ and south $(p=0.003)$ shelf regions (Supplemental Figure 3).

\section{Variably Methylated Probes and Regions}

Regional analysis identified 10 variably methylated regions (VMRs) signficant from a total of 11,055 candidate VMRs (FDR 17.3\%). Seven of the VMRs mapped onto genes (Table 3). Significant VMRs were all more variable in MD cases, and the number of $\mathrm{CpG}$ probes in these regions ranged from 2 to 11 (median=4). The VMP analysis yielded 560 significant VMP findings (FDR 1\%), all of which were more variable in MD cases except for a single probe (Supplemental Table 3). The combined set of VMR and VMP DNA regions of $16.6 \mathrm{~Kb}$ reflected a nonrandom enrichment with ChromHMM annotations for $5^{\prime} / 3^{\prime}$ transcription $(p=$ $0.035)$, genic enhancers $(p=0.024)$ and heterochromatin $(p=0.050)$ (Supplemental Figure 4) and $\mathrm{CpG}$ island relationships within the south shelf $(p=0.029)$ (Supplemental Figure 5).

\section{Gene Enrichment Analysis}

Genes that mapped to signficant differentially or variably methylated findings were combined for gene-based enrichment to provide an overview of all DNAm contributions at a functional level. The results of enrichment tests yielded significant over-representation for biological processes (BP) and cellular function (CF), and no enrichment for molecular function or KEGG, at the 
10\% FDR (Table 4). The BP gene category associations were hemophilic cell adhesion and cellcell adhesion while the significant terms for CF were associated with functions of neurons, including neuron projection terminus, terminal button, axon part, cell projection part, axon, and presynapse.

\section{Relationship Between Early-Onset MD DNAm Markers and PGC MD-Associated}

\section{Genetic Loci}

A total of 6 differentially methylated sites (including DMP/DMRs; $p=0.002 ; 95 \% \mathrm{Cl}=2$ 11) (Supplemental Table 4) and 12 variably methylated sites (including VMPs/VMRs; $95 \% \mathrm{CI}=$ 5-19, $p=0.008$ ) (Supplemental Table 5) overlapped PGC GWAS findings. These enrichment results were largely driven by overlap observed with the PGC GWAS locus on chromosome 6 at 27.738-32.848 Mb (Figure 1). At this locus, 5 of 6 differentially and 10 of 12 variably methylated sites overlapped.

\section{Discussion}

The main objective of the current study was to identify differentially and variably methylated loci and regions that distinguish MZ twins with and without a history of early-onset MD. Across biological process (BP) and cellular function (CF) domains of the gene enrichment analysis, there was consistency in the functional attributes of the genes related to neural structures and processes as a key differentiating feature between MD affected and unaffected twins. BP gene ontologies referenced homophilic cell adhesion and cell-cell adhesion processes, which are involved in neural development and plasticity. A number of cadherins and protocadherins emerged in the cell adhesion gene sets with MD affected twins demonstrating increased variation in two cadherins $(\mathrm{CDH} 3, \mathrm{CDH})$, the clustered protocadherin alpha family (PCHDA1 - PCDHA13), the C-type isoforms of PCDHA (PCDHAC1, PCDHAC2), and two non-clustered Protocadherins (PCDH10, PCDH20). CDHs/PCDHs are a group of calcium dependent cell-cell adhesion molecules that are abundantly expressed in the nervous system and play a major role in multiple steps 
essential to neurodevelopment including dendrite arborization, axon outgrowth and targeting, synaptogenesis, and synapse elimination ${ }^{60-66}$.

The DNAm profile of the $P C D H s$ is known to be responsive to environmental factors ${ }^{67}$, and emerging evidence suggests a role for PCDHs in multiple psychiatric phenotypes (e.g., schizophrenia, bipolar disorder, autism) including $\mathrm{MD}^{68,69}$. Two small twin studies observed that several cadherin/protocadherin genes demonstrated differences in DNAm between twin pairs repeatedly discordant for elevated depression symptoms ${ }^{70}$ as well as a history of MD or an anxiety disorder ${ }^{71}$. A related study observed increased DNAm in $P C D H$ gene families with the highest enrichment of hypermethylated sites in the PCDHA genes located in the hippocampus of suicide completers with a history of severe childhood abuse ${ }^{19}$. At the genetic variant level, a recent meta-analysis with over 89,000 MD cases detected a SNP (rs9540720) in the non-clustered PCDH9 gene to be significantly associated with MD case status at the genome-wide level ${ }^{72}$, and a related gene that encodes a protein of the same family $(P C D H 17)$ was found to confer risk for mood disorders ${ }^{73}$. Moreover, expression patterns of Pcdh genes have been examined in rodent brain regions involved in the neural circuity of $\mathrm{MD}^{74}$, with results indicating high expression levels in subregions of the hippocampus and basolateral amygdaloid complex ${ }^{74,75}$. Moreover, Pcdh gene expression was reduced in both structures following electroconvulsive shock (ECS), which is interesting given that ECS is an effective treatment for chronic, intractable MD symptomatology ${ }^{76}$ and supports involvement of $P C D H s$ in neural plasticity. The clustered $P C D H A$ family also is strongly expressed in serotonergic neurons ${ }^{77-79}$ and PcdhaC2 is necessary for axonal tiling and assembly of serotonergic circuitries ${ }^{86}$. Thus, a deeper understanding of how the serotonergic neural network is formed in the young developing brain may be critical to identifying etiological determinants of MD and other psychiatric conditions.

The Histone Deacetylase 4 (HDAC4) gene was altered in MD affected twins, exhibiting increased variation and emerging as part of a genomic region displaying higher mean levels com- 
pared to MD unaffected twins ${ }^{80}$. HDAC4 is highly expressed in the human brain, ${ }^{81}$ and the subcellular localization of the HDAC4 protein is purportedly modulated by $N$-methyl-D-aspartate (NMDA) receptors, a specific type of ionotropic glutamate receptor important for controlling synaptic plasticity and memory function ${ }^{82}$. In humans, increased HDAC4 expression is associated with memory deficits ${ }^{80,82}$, which is consistent with the cognitive processing difficulties observed with $\mathrm{MD}^{83,84}$. Moreover, drugs that inhibit HDAC4 have antidepressant-like effects on behavior ${ }^{85-}$ 88. Similarly, Neuroregulin1 (NRG1) exhibited increased variation and emerged in the gene enrichment analysis as a gene involved in multiple cellular functions. NRG1 promotes myelination in the central nervous system (CNS) and evidence suggests an association between NRG1 and cognitive deficits linked to psychiatric disorders ${ }^{89,89-95}$.

The overlap between our DNAm results and variants identified in the latest PGC GWAS of depression were examined to better understand the possible role of early-onset MD DNAm events among these genetic associations. A total of 6 differentially methylated and 12 variably methylated sites overlapped PGC findings. These enrichment results were primarily driven by overlap observed with the PGC GWAS locus on chromosome 6, which falls in the extended $\mathrm{MHC}$ region. This region of the genome also was the most significant association in the PGC's GWAS of schizophrenia ${ }^{96}$ and a GWAS that included a combined sample of schizophrenia and bipolar disorder cases ${ }^{97}$. The MHC is densely populated with genes related to neuronal signaling and plays a role in immune functioning. MHC findings are consistent with evidence of an immune component involved in the pathophysiology of psychiatric conditions.

A number of additional genes/gene regions previously linked to MD (e.g., CX3CR1, CACNA1A, CDC42BPB) $)^{99,102-104}$. For example, serotonin related genes, HTR5A and HTR5A-AS1, exhibited greater variance in MD affected twins. This gene is a member of the $5 \mathrm{HT}$ (serotonin) receptor family, which has been implicated in MD and other psychiatric conditions ${ }^{105-107}$. Related, corticotropin releasing hormone receptor $2(C R H R 2)$ and cholinergic receptor nicotinic beta 2 subunit (CHRNB2) demonstrated increased variance in MD affected twins. Thus, complex genetic 
disorders such as MD reflect a large number of independent genetic factors that each contribute a small amount of variance to disease susceptibility and multiple psychiatric diseases likely share genetic risk factors.

Limitations associated with the current study design include its reliance on an all Caucasian sample, which diminishes generalizability of findings to other races. The current study also relied on peripheral blood tissue for DNAm. Although brain tissue is preferred to study the pathophysiology of MD, evidence suggests moderate consistency in DNAm between blood and brain tissues $^{15,71}$. Consistent with epidemiological findings ${ }^{108}$, females represented the majority of the sample. Thus, increased numbers of males are needed to determine potential sex-related differences. The cross-sectional design of the current study also does not allow for determination of epigenetic differences as cause or consequence of MD onset. Strengths of the current study design include its use of the $M Z$ co-twin control method in conjunction with a sensitive developmental window to reveal genome-wide DNAm biomarkers associated with early-onset MD. 


\section{References}

1. Kessler RC, Berglund P, Demler O, et al. The epidemiology of major depressive disorder: results from the National Comorbidity Survey Replication (NCS-R). JAMA. 2003;289(23):3095-3105. doi:10.1001/jama.289.23.3095

2. Weissman MM, Wolk S, Goldstein RB, et al. Depressed adolescents grown up. JAMA. 1999;281(18):1707-1713.

3. Lewinsohn PM, Rohde P, Seeley JR. Major depressive disorder in older adolescents: prevalence, risk factors, and clinical implications. Clin Psychol Rev. 1998;18(7):765-794.

4. Saluja G, lachan R, Scheidt PC, Overpeck MD, Sun W, Giedd JN. Prevalence of and risk factors for depressive symptoms among young adolescents. Arch Pediatr Adolesc Med. 2004;158(8):760-765. doi:10.1001/archpedi.158.8.760

5. Kerestes R, Davey CG, Stephanou K, Whittle S, Harrison BJ. Functional brain imaging studies of youth depression: a systematic review. Neuroimage Clin. 2014;4:209-231. doi:10.1016/j.nicl.2013.11.009

6. Hankin BL, Abramson LY, Moffitt TE, Silva PA, McGee R, Angell KE. Development of depression from preadolescence to young adulthood: emerging gender differences in a 10-year longitudinal study. J Abnorm Psychol. 1998;107(1):128-140.

7. Weissman MM, Wolk S, Wickramaratne $P$, et al. Children with prepubertal-onset major depressive disorder and anxiety grown up. Arch Gen Psychiatry. 1999;56(9):794-801.

8. Costello EJ, Mustillo S, Erkanli A, Keeler G, Angold A. Prevalence and development of psychiatric disorders in childhood and adolescence. Arch Gen Psychiatry. 2003;60(8):837-844. doi:10.1001/archpsyc.60.8.837

9. Sullivan PF, Neale MC, Kendler KS. Genetic epidemiology of major depression: review and meta-analysis. Am J Psychiatry. 2000;157(10):1552-1562.

doi:10.1176/appi.ajp.157.10.1552

10. Wray NR, Sullivan PF. Genome-wide association analyses identify 44 risk variants and refine the genetic architecture of major depression. July 2017. doi:10.1101/167577

11. Sullivan PF, Neale MC, Kendler KS. Genetic epidemiology of major depression: review and meta-analysis. Am J Psychiatry. 2000;157(10):1552-1562.

doi:10.1176/appi.ajp.157.10.1552

12. Kendler KS, Kessler RC, Walters EE, et al. Stressful life events, genetic liability, and onset of an episode of major depression in women. Am J Psychiatry. 1995;152(6):833-842. doi:10.1176/ajp.152.6.833

13. Kessler RC. The effects of stressful life events on depression. Annu Rev Psychol. 1997;48:191-214. doi:10.1146/annurev.psych.48.1.191 
14. Klengel T, Pape J, Binder EB, Mehta D. The role of DNA methylation in stress-related psychiatric disorders. Neuropharmacology. 2014;80:115-132. doi:10.1016/j.neuropharm.2014.01.013

15. Bagot RC, Labonte B, Pena CJ, Nestler EJ. Epigenetic signaling in psychiatric disorders: stress and depression. Dialogues Clin Neurosci. 2014;16(3):281-295.

16. Szyf M, McGowan P, Meaney MJ. The social environment and the epigenome. Environ Mol Mutagen. 2008;49(1):46-60. doi:10.1002/em.20357

17. Weaver ICG, Cervoni N, Champagne FA, et al. Epigenetic programming by maternal behavior. Nat Neurosci. 2004;7(8):847-854. doi:10.1038/nn1276

18. Weaver ICG, Szyf M, Meaney MJ. From maternal care to gene expression: DNA methylation and the maternal programming of stress responses. Endocr Res. 2002;28(4):699.

19. Suderman M, McGowan PO, Sasaki A, et al. Conserved epigenetic sensitivity to early life experience in the rat and human hippocampus. Proc Natl Acad Sci U S A. 2012;109 Suppl 2:17266-17272. doi:10.1073/pnas.1121260109

20. Fish EW, Shahrokh D, Bagot R, et al. Epigenetic programming of stress responses through variations in maternal care. Ann N Y Acad Sci. 2004;1036:167-180. doi:10.1196/annals.1330.011

21. Meaney MJ, Szyf M, Seckl JR. Epigenetic mechanisms of perinatal programming of hypothalamic-pituitary-adrenal function and health. Trends Mol Med. 2007;13(7):269277. doi:10.1016/j.molmed.2007.05.003

22. McGowan PO, Suderman M, Sasaki $A$, et al. Broad epigenetic signature of maternal care in the brain of adult rats. PLoS One. 2011;6(2):e14739. doi:10.1371/journal.pone.0014739

23. Borrelli E, Nestler EJ, Allis CD, Sassone-Corsi P. Decoding the epigenetic language of neuronal plasticity. Neuron. 2008;60(6):961-974. doi:10.1016/j.neuron.2008.10.012

24. Anacker C, O'Donnell KJ, Meaney MJ. Early life adversity and the epigenetic programming of hypothalamic-pituitary-adrenal function. Dialogues Clin Neurosci. 2014;16(3):321-333.

25. McGowan PO, Sasaki A, D'Alessio AC, et al. Epigenetic regulation of the glucocorticoid receptor in human brain associates with childhood abuse. Nat Neurosci. 2009;12(3):342348. doi:10.1038/nn.2270

26. Szyf M, Weaver I, Meaney M. Maternal care, the epigenome and phenotypic differences in behavior. Reprod Toxicol. 2007;24(1):9-19. doi:10.1016/j.reprotox.2007.05.001

27. Zhang TY, Labonte B, Wen XL, Turecki G, Meaney MJ. Epigenetic mechanisms for the early environmental regulation of hippocampal glucocorticoid receptor gene expression in rodents and humans. Neuropsychopharmacology. 2013;38(1):111-123.

doi:10.1038/npp.2012.149 
28. Szyf M. The early life environment and the epigenome. Biochim Biophys Acta. 2009;1790(9):878-885. doi:10.1016/j.bbagen.2009.01.009

29. Lappalainen T, Greally JM. Associating cellular epigenetic models with human phenotypes. Nat Rev Genet. 2017;18(7):441-451. doi:10.1038/nrg.2017.32

30. Grundberg E, Meduri E, Sandling JK, et al. Global Analysis of DNA Methylation Variation in Adipose Tissue from Twins Reveals Links to Disease-Associated Variants in Distal Regulatory Elements. The American Journal of Human Genetics. 2013;93(5):876-890. doi:10.1016/j.ajhg.2013.10.004

31. Bell JT, Pai AA, Pickrell JK, et al. DNA methylation patterns associate with genetic and gene expression variation in HapMap cell lines. Genome Biol. 2011;12(1):R10. doi:10.1186/gb-2011-12-1-r10

32. Chen L, Ge B, Casale FP, et al. Genetic Drivers of Epigenetic and Transcriptional Variation in Human Immune Cells. Cell. 2016;167(5):1398-1414.e24. doi:10.1016/j.cell.2016.10.026

33. Banovich NE, Lan X, McVicker G, et al. Methylation QTLs are associated with coordinated changes in transcription factor binding, histone modifications, and gene expression levels. PLoS Genet. 2014;10(9):e1004663. doi:10.1371/journal.pgen.1004663

34. Zhang D, Cheng L, Badner JA, et al. Genetic control of individual differences in genespecific methylation in human brain. Am J Hum Genet. 2010;86(3):411-419. doi:10.1016/j.ajhg.2010.02.005

35. Oh G, Wang S-C, Pal M, et al. DNA modification study of major depressive disorder: beyond locus-by-locus comparisons. Biol Psychiatry. 2015;77(3):246-255. doi:10.1016/j.biopsych.2014.06.016

36. Zeng Q, Chen X, Ning C, et al. Methylation of the genes ROD1, NLRC5, and HKR1 is associated with aging in Hainan centenarians. BMC Med Genomics. 2018;11(1):7. doi:10.1186/s12920-018-0334-1

37. Unnikrishnan A, Hadad N, Masser DR, Jackson J, Freeman WM, Richardson A. Revisiting the genomic hypomethylation hypothesis of aging. Ann N Y Acad Sci. 2018;1418(1):6979. doi:10.1111/nyas. 13533

38. Masser DR, Hadad N, Porter $\mathrm{H}$, et al. Analysis of DNA modifications in aging research. Geroscience. 2018;40(1):11-29. doi:10.1007/s11357-018-0005-3

39. Levesque ML, Casey KF, Szyf M, et al. Genome-wide DNA methylation variability in adolescent monozygotic twins followed since birth. Epigenetics. 2014;9(10):1410-1421. doi:10.4161/15592294.2014.970060

40. Cecilione JL, Rappaport LM, Hahn SE, et al. Genetic and Environmental Contributions of Negative Valence Systems to Internalizing Pathways. Twin Res Hum Genet.

2018;21(1):12-23. doi:10.1017/thg.2017.72 
41. Lilley ECH, Silberg JL. The Mid-Atlantic Twin Registry, revisited. Twin Res Hum Genet. 2013;16(1):424-428. doi:10.1017/thg.2012.125

42. Bachmann CJ, Aagaard L, Burcu M, et al. Trends and patterns of antidepressant use in children and adolescents from five western countries, 2005-2012. Eur Neuropsychopharmacol. 2016;26(3):411-419. doi:10.1016/j.euroneuro.2016.02.001

43. Kessler RC, Ustun TB. The World Mental Health (WMH) Survey Initiative Version of the World Health Organization (WHO) Composite International Diagnostic Interview (CIDI). Int J Methods Psychiatr Res. 2004;13(2):93-121.

44. Daviss WB, Birmaher B, Melhem NA, Axelson DA, Michaels SM, Brent DA. Criterion validity of the Mood and Feelings Questionnaire for depressive episodes in clinic and non-clinic subjects. J Child Psychol Psychiatry. 2006;47(9):927-934. doi:10.1111/j.14697610.2006.01646.x

45. Ong M-L, Holbrook JD. Novel region discovery method for Infinium 450K DNA methylation data reveals changes associated with aging in muscle and neuronal pathways. Aging Cell. 2014;13(1):142-155. doi:10.1111/acel.12159

46. Jaffe $A E$, Murakami $P$, Lee $H$, et al. Bump hunting to identify differentially methylated regions in epigenetic epidemiology studies. Int J Epidemiol. 2012;41(1):200-209. doi:10.1093/ije/dyr238

47. Lee $\mathrm{H}$, Jaffe AE, Feinberg JI, et al. DNA methylation shows genome-wide association of NFIX, RAPGEF2 and MSRB3 with gestational age at birth. Int J Epidemiol. 2012;41(1):188-199. doi:10.1093/ije/dyr237

48. Jaffe AE, Feinberg AP, Irizarry RA, Leek JT. Significance analysis and statistical dissection of variably methylated regions. Biostatistics. 2012;13(1):166-178.

doi:10.1093/biostatistics/kxr013

49. Butcher LM, Beck S. Probe Lasso: a novel method to rope in differentially methylated regions with 450K DNA methylation data. Methods. 2015;72:21-28.

doi:10.1016/j.ymeth.2014.10.036

50. Wright ML, Dozmorov MG, Wolen AR, et al. Establishing an analytic pipeline for genomewide DNA methylation. Clin Epigenetics. 2016;8:45. doi:10.1186/s13148-016-0212-7

51. Hochberg Y, Benjamini Y. More powerful procedures for multiple significance testing. Stat Med. 1990;9(7):811-818.

52. Bates M, Martin M, Bolker B, Walker S. Fitting linear mixed-effects models using Ime4. Journal of Statistical Software. 2015;67(1):1-48.

53. Tusher VG, Tibshirani R, Chu G. Significance analysis of microarrays applied to the ionizing radiation response. Proc Natl Acad Sci U S A. 2001;98(9):5116-5121.

doi:10.1073/pnas.091062498

54. R Core Team. A Language and Environment for Statistical Computing. Vienna, Austria: R Foundation for Statistical Computing; 2013. 
55. Carlson MRJ, Pages H, Arora S, Obenchain V, Morgan M. Genomic Annotation Resources in R/Bioconductor. Methods Mol Biol. 2016;1418:67-90. doi:10.1007/978-1-4939-35789_4

56. Ashburner M, Ball CA, Blake JA, et al. Gene ontology: tool for the unification of biology. The Gene Ontology Consortium. Nat Genet. 2000;25(1):25-29. doi:10.1038/75556

57. Yu G, Wang L-G, Han Y, He Q-Y. clusterProfiler: an R package for comparing biological themes among gene clusters. OMICS. 2012;16(5):284-287. doi:10.1089/omi.2011.0118

58. Martin Morgan. AnnotationHub: Client to access AnnotationHub resource.

59. Faraway JJ. Extending the Linear Model with R: Generalized Linear, Mixed Effects and Nonparametric Regression Models. New York: Chapman and Hall; 2006.

60. Peek SL, Mah KM, Weiner JA. Regulation of neural circuit formation by protocadherins. Cell Mol Life Sci. 2017;74(22):4133-4157. doi:10.1007/s00018-017-2572-3

61. Lefebvre JL, Kostadinov D, Chen WV, Maniatis T, Sanes JR. Protocadherins mediate dendritic self-avoidance in the mammalian nervous system. Nature. 2012;488(7412):517521. doi:10.1038/nature11305

62. Suo L, Lu H, Ying G, Capecchi MR, Wu Q. Protocadherin clusters and cell adhesion kinase regulate dendrite complexity through Rho GTPase. J Mol Cell Biol. 2012;4(6):362-376. doi:10.1093/jmcb/mjs034

64. Chen WV, Maniatis T. Clustered protocadherins. Development. 2013;140(16):3297-3302. doi:10.1242/dev.090621

65. Hayashi S, Takeichi M. Emerging roles of protocadherins: from self-avoidance to enhancement of motility. J Cell Sci. 2015;128(8):1455-1464. doi:10.1242/jcs.166306

66. Hirano S, Takeichi M. Cadherins in brain morphogenesis and wiring. Physiol Rev. 2012;92(2):597-634. doi:10.1152/physrev.00014.2011

67. Hirayama T, Yagi T. Regulation of clustered protocadherin genes in individual neurons. Semin Cell Dev Biol. 2017;69:122-130. doi:10.1016/j.semcdb.2017.05.026

68. Pedrosa E, Stefanescu R, Margolis B, et al. Analysis of protocadherin alpha gene enhancer polymorphism in bipolar disorder and schizophrenia. Schizophr Res. 2008;102(1-3):210219. doi:10.1016/j.schres.2008.04.013

69. Anitha A, Thanseem I, Nakamura K, et al. Protocadherin alpha (PCDHA) as a novel susceptibility gene for autism. J Psychiatry Neurosci. 2013;38(3):192-198. doi:10.1503/jpn.120058

70. Dempster EL, Wong CCY, Lester KJ, et al. Genome-wide methylomic analysis of monozygotic twins discordant for adolescent depression. Biol Psychiatry. 2014;76(12):977-983. doi:10.1016/j.biopsych.2014.04.013 
71. Cordova-Palomera A, Fatjo-Vilas M, Gasto C, Navarro V, Krebs M-O, Fananas L. Genomewide methylation study on depression: differential methylation and variable methylation in monozygotic twins. Transl Psychiatry. 2015;5:e557. doi:10.1038/tp.2015.49

72. Xiao X, Zheng F, Chang H, et al. The Gene Encoding Protocadherin 9 (PCDH9), a Novel Risk Factor for Major Depressive Disorder. Neuropsychopharmacology. 2018;43(5):11281137. doi:10.1038/npp.2017.241

73. Chang $\mathrm{H}$, Hoshina $\mathrm{N}$, Zhang $\mathrm{C}$, et al. The protocadherin 17 gene affects cognition, personality, amygdala structure and function, synapse development and risk of major mood disorders. Mol Psychiatry. 2018;23(2):400-412. doi:10.1038/mp.2016.231

74. Russo SJ, Nestler EJ. The brain reward circuitry in mood disorders. Nat Rev Neurosci. 2013;14(9):609-625. doi:10.1038/nrn3381

75. Kim SY, Mo JW, Han S, et al. The expression of non-clustered protocadherins in adult rat hippocampal formation and the connecting brain regions. Neuroscience. 2010;170(1):189-199. doi:10.1016/j.neuroscience.2010.05.027

76. Weiner RD, Reti IM. Key updates in the clinical application of electroconvulsive therapy. Int Rev Psychiatry. 2017;29(2):54-62. doi:10.1080/09540261.2017.1309362

77. Yoshinaga S, Nakajima K. A crossroad of neuronal diversity to build circuitry. Science. 2017;356(6336):376-377. doi:10.1126/science.aan2856

78. Katori S, Hamada S, Noguchi Y, et al. Protocadherin-alpha family is required for serotonergic projections to appropriately innervate target brain areas. J Neurosci. 2009;29(29):9137-9147. doi:10.1523/JNEUROSCI.5478-08.2009

79. Katori S, Noguchi-Katori Y, Okayama A, et al. Protocadherin-alphaC2 is required for diffuse projections of serotonergic axons. Sci Rep. 2017;7(1):15908. doi:10.1038/s41598-017$16120-y$

80. Wu Y, Hou F, Wang X, Kong Q, Han X, Bai B. Aberrant Expression of Histone Deacetylases 4 in Cognitive Disorders: Molecular Mechanisms and a Potential Target. Front Mol Neurosci. 2016;9:114. doi:10.3389/fnmol.2016.00114

81. Uchida S, Shumyatsky GP. Synaptically Localized Transcriptional Regulators in Memory Formation. Neuroscience. 2018;370:4-13. doi:10.1016/j.neuroscience.2017.07.023

82. Kim M-S, Akhtar MW, Adachi M, et al. An essential role for histone deacetylase 4 in synaptic plasticity and memory formation. J Neurosci. 2012;32(32):10879-10886. doi:10.1523/JNEUROSCI.2089-12.2012

83. MacQueen GM, Memedovich KA. Cognitive dysfunction in major depression and bipolar disorder: Assessment and treatment options. Psychiatry Clin Neurosci. 2017;71(1):18-27. doi:10.1111/pcn.12463

84. Talarowska M, Berk M, Maes M, Galecki P. Autobiographical memory dysfunctions in depressive disorders. Psychiatry Clin Neurosci. 2016;70(2):100-108.

doi:10.1111/pen.12370 
85. Covington HE 3rd, Maze I, Vialou V, Nestler EJ. Antidepressant action of HDAC inhibition in the prefrontal cortex. Neuroscience. 2015;298:329-335.

doi:10.1016/j.neuroscience.2015.04.030

86. Covington HE 3rd, Maze I, LaPlant QC, et al. Antidepressant actions of histone deacetylase inhibitors. J Neurosci. 2009;29(37):11451-11460. doi:10.1523/JNEUROSCI.1758-09.2009

87. Covington HE 3rd, Vialou VF, LaPlant Q, Ohnishi YN, Nestler EJ. Hippocampal-dependent antidepressant-like activity of histone deacetylase inhibition. Neurosci Lett.

2011;493(3):122-126. doi:10.1016/j.neulet.2011.02.022

88. Meylan EM, Halfon O, Magistretti PJ, Cardinaux J-R. The HDAC inhibitor SAHA improves depressive-like behavior of CRTC1-deficient mice: Possible relevance for treatmentresistant depression. Neuropharmacology. 2016;107:111-121. doi:10.1016/j.neuropharm.2016.03.012

89. Bi L-L, Sun X-D, Zhang J, et al. Amygdala NRG1-ErbB4 is critical for the modulation of anxiety-like behaviors. Neuropsychopharmacology. 2015;40(4):974-986. doi:10.1038/npp.2014.274

90. Wang Y-N, Figueiredo D, Sun X-D, et al. Controlling of glutamate release by neuregulin3 via inhibiting the assembly of the SNARE complex. Proc Natl Acad Sci U S A. 2018;115(10):2508-2513. doi:10.1073/pnas.1716322115

91. Chong VZ, Thompson M, Beltaifa S, Webster MJ, Law AJ, Weickert CS. Elevated neuregulin-1 and ErbB4 protein in the prefrontal cortex of schizophrenic patients. Schizophr Res. 2008;100(1-3):270-280. doi:10.1016/j.schres.2007.12.474

92. Wen Z, Chen J, Khan RAW, et al. Genetic association between NRG1 and schizophrenia, major depressive disorder, bipolar disorder in Han Chinese population. Am J Med Genet B Neuropsychiatr Genet. 2016;171B(3):468-478. doi:10.1002/ajmg.b.32428

93. Mostaid MS, Lloyd D, Liberg B, et al. Neuregulin-1 and schizophrenia in the genome-wide association study era. Neurosci Biobehav Rev. 2016;68:387-409. doi:10.1016/j.neubiorev.2016.06.001

94. McIntosh AM, Hall J, Lymer GKS, Sussmann JED, Lawrie SM. Genetic risk for white matter abnormalities in bipolar disorder. Int Rev Psychiatry. 2009;21(4):387-393. doi:10.1080/09540260902962180

95. Chen X, Long F, Cai B, Chen X, Qin L, Chen G. A Novel Relationship for Schizophrenia, Bipolar, and Major Depressive Disorder. Part 8: a Hint from Chromosome 8 High Density Association Screen. Mol Neurobiol. 2017;54(8):5868-5882. doi:10.1007/s12035-0160102-1

96. Biological insights from 108 schizophrenia-associated genetic loci. Nature. 2014;511(7510):421-427. doi:10.1038/nature13595

97. Ruderfer DM, Fanous AH, Ripke S, et al. Polygenic dissection of diagnosis and clinical dimensions of bipolar disorder and schizophrenia. Mol Psychiatry. 2014;19(9):1017-1024. doi:10.1038/mp.2013.138 
98. Sekar A, Bialas AR, de Rivera $\mathrm{H}$, et al. Schizophrenia risk from complex variation of complement component 4. Nature. 2016;530(7589):177-183. doi:10.1038/nature16549

99. Athanasiu L, Giddaluru S, Fernandes C, et al. A genetic association study of CSMD1 and CSMD2 with cognitive function. Brain Behav Immun. 2017;61:209-216.

doi:10.1016/j.bbi.2016.11.026

100. Donohoe G, Walters J, Hargreaves A, et al. Neuropsychological effects of the CSMD1 genome-wide associated schizophrenia risk variant rs10503253. Genes Brain Behav. 2013;12(2):203-209. doi:10.1111/gbb.12016

101. Koiliari E, Roussos P, Pasparakis E, et al. The CSMD1 genome-wide associated schizophrenia risk variant rs 10503253 affects general cognitive ability and executive function in healthy males. Schizophr Res. 2014;154(1-3):42-47. doi:10.1016/j.schres.2014.02.017

102. Sherva R, Wang Q, Kranzler H, et al. Genome-wide Association Study of Cannabis Dependence Severity, Novel Risk Variants, and Shared Genetic Risks. JAMA Psychiatry. 2016;73(5):472-480. doi:10.1001/jamapsychiatry.2016.0036

103. Lotan A, Fenckova M, Bralten J, et al. Neuroinformatic analyses of common and distinct genetic components associated with major neuropsychiatric disorders. Front Neurosci. 2014;8:331. doi:10.3389/fnins.2014.00331

104. Story Jovanova O, Nedeljkovic I, Derek S, et al. DNA Methylation Signatures of Depressive Symptoms in Middle-aged and Elderly Persons: Meta-analysis of Multiethnic Epigenome-wide Studies. JAMA Psychiatry. July 2018. doi:10.1001/jamapsychiatry.2018.1725

105. Brezo J, Bureau A, Merette C, et al. Differences and similarities in the serotonergic diathesis for suicide attempts and mood disorders: a 22-year longitudinal geneenvironment study. Mol Psychiatry. 2010;15(8):831-843. doi:10.1038/mp.2009.19

106. Dong Z-Q, Li X-R, He L, He G, Yu T, Sun X-L. 5-HTR1A and 5-HTR2A genetic polymorphisms and SSRI antidepressant response in depressive Chinese patients. Neuropsychiatr Dis Treat. 2016;12:1623-1629. doi:10.2147/NDT.S93562

107. Yosifova A, Mushiroda T, Stoianov D, et al. Case-control association study of 65 candidate genes revealed a possible association of a SNP of HTR5A to be a factor susceptible to bipolar disease in Bulgarian population. J Affect Disord. 2009;117(1-2):87-97. doi:10.1016/j.jad.2008.12.021

108. Hasin DS, Sarvet AL, Meyers JL, et al. Epidemiology of Adult DSM-5 Major Depressive Disorder and Its Specifiers in the United States. JAMA Psychiatry. 2018;75(4):336-346. doi:10.1001/jamapsychiatry.2017.4602

109. American Psychiatric Association. Diagnostic and Statistical Manual of Mental Disorders, 5th Edition.; 2013. 
110. Kendler KS, Neale MC, Kessler RC, Heath AC, Eaves LJ. A population-based twin study of major depression in women. The impact of varying definitions of illness. Arch Gen Psychiatry. 1992;49(4):257-266.

111. Meier A. The research diagnostic criteria: historical background, development, validity, and reliability. Can J Psychiatry. 1979;24(2):167-178.

112. Endicott J, Spitzer RL. Use of the Research Diagnostic Criteria and the Schedule for Affective Disorders and Schizophrenia to study affective disorders. Am J Psychiatry. 1979;136(1):52-56. doi:10.1176/ajp.136.1.52

113. Spitzer RL, Endicott J, Robins E. Research diagnostic criteria. Psychopharmacol Bull. 1975;11(3):22-25.

114. Spitzer RL, Endicott J, Robins E. Research diagnostic criteria: rationale and reliability. Arch Gen Psychiatry. 1978;35(6):773-782.

115. Kasriel J, Eaves L. The zygosity of twins: further evidence on the agreement between diagnosis by blood groups and written questionnaires. J Biosoc Sci. 1976;8(3):263-266.

116. Jackson RW, Snieder H, Davis H, Treiber FA. Determination of twin zygosity: a comparison of DNA with various questionnaire indices. Twin Res. 2001;4(1):12-18.

117. Bibikova M, Barnes B, Tsan C, et al. High density DNA methylation array with single CpG site resolution. Genomics. 2011;98(4):288-295. doi:10.1016/j.ygeno.2011.07.007

118. Morris TJ, Beck S. Analysis pipelines and packages for Infinium HumanMethylation450 BeadChip (450k) data. Methods. 2015;72:3-8. doi:10.1016/j.ymeth.2014.08.011

119. Aryee MJ, Jaffe AE, Corrada-Bravo H, et al. Minfi: a flexible and comprehensive Bioconductor package for the analysis of Infinium DNA methylation microarrays. Bioinformatics. 2014;30(10):1363-1369. doi:10.1093/bioinformatics/btu049

120. Barfield RT, Almli LM, Kilaru V, et al. Accounting for population stratification in DNA methylation studies. Genet Epidemiol. 2014;38(3):231-241. doi:10.1002/gepi.21789

121. Du P, Zhang X, Huang C-C, et al. Comparison of Beta-value and M-value methods for quantifying methylation levels by microarray analysis. BMC Bioinformatics. 2010;11:587. doi:10.1186/1471-2105-11-587

122. Chen $Y$, Lemire M, Choufani S, et al. Discovery of cross-reactive probes and polymorphic CpGs in the Illumina Infinium HumanMethylation450 microarray. Epigenetics. 2013;8(2):203-209. doi:10.4161/epi.23470

123. Touleimat N, Tost J. Complete pipeline for Infinium((R)) Human Methylation $450 \mathrm{~K}$ BeadChip data processing using subset quantile normalization for accurate DNA methylation estimation. Epigenomics. 2012;4(3):325-341. doi:10.2217/epi.12.21

124. Leek JT, Scharpf RB, Bravo HC, et al. Tackling the widespread and critical impact of batch effects in high-throughput data. Nat Rev Genet. 2010;11(10):733-739.

doi:10.1038/nrg2825 
bioRxiv preprint doi: https://doi.org/10.1101/422345; this version posted November 1, 2018. The copyright holder for this preprint (which was not certified by peer review) is the author/funder, who has granted bioRxiv a license to display the preprint in perpetuity. It is made available under aCC-BY-NC-ND 4.0 International license.

125. Leek JT, Johnson WE, Parker HS, Jaffe AE, Storey JD. The sva package for removing batch effects and other unwanted variation in high-throughput experiments.

Bioinformatics. 2012;28(6):882-883. doi:10.1093/bioinformatics/bts034

126. Houseman EA, Kelsey KT, Wiencke JK, Marsit CJ. Cell-composition effects in the analysis of DNA methylation array data: a mathematical perspective. BMC Bioinformatics.

2015;16:95. doi:10.1186/s12859-015-0527-y 
bioRxiv preprint doi: https://doi.org/10.1101/422345; this version posted November 1, 2018. The copyright holder for this preprint (which was not certified by peer review) is the author/funder, who has granted bioRxiv a license to display the preprint in perpetuity. It is made available under aCC-BY-NC-ND 4.0 International license.

\section{Acknowledgements}

The research outcomes presented in this manuscript were supported by a NARSAD Independent Investigator Award from the Brain and Behavior Research Foundation to the first author (RRN).

The development of analytic methods were supported by a NARSAD Independent Investigator Award from the Brain and Behavior Research Foundation to the last author (TPY). 
Table 1. Demographic and clinical characteristics of twins meeting definite or probable DSM-5 criteria for lifetime history of MD (MD Affected) versus no lifetime history of MD (MD Unaffected).

\begin{tabular}{|c|c|c|c|c|}
\hline & \multicolumn{2}{|c|}{$M(\mathrm{SD})$ or $\mathrm{n}(\%)$} & \multirow[b]{2}{*}{$t / \chi^{2}$} & \multirow[b]{2}{*}{$p$} \\
\hline & $\begin{array}{c}\text { MD Unaffected } \\
n=111\end{array}$ & $\begin{array}{c}\text { MD Affected } \\
n=39\end{array}$ & & \\
\hline \multicolumn{5}{|l|}{ Demographic/Sample } \\
\hline Age, years & $17.49(1.3)$ & $17.60(1.3)$ & 0.66 & 0.51 \\
\hline Sex, Female & $81(73.0 \%)$ & $29(74.4 \%)$ & 0.28 & 0.87 \\
\hline Ethnicity, Hispanic & $5(4.5 \%)$ & $3(7.7 \%)$ & 0.58 & 0.43 \\
\hline Nicotine Use ${ }^{\S}$, Current Smoker & $2(1.8 \%)$ & $3(7.7 \%)$ & 3.11 & 0.11 \\
\hline \multicolumn{5}{|l|}{ Clinical Characteristics } \\
\hline SMFQ & $4.4(3.7)$ & $9.0(6.0)$ & 6.40 & $<.001$ \\
\hline History of psychotropic medication use & $2(1.8 \%)$ & $4(10.3 \%)$ & 0.64 & 0.62 \\
\hline Panic Disorder & $5(4.5 \%)$ & $3(7.7 \%)$ & 0.56 & 0.43 \\
\hline Social Anxiety Disorder & $10(9.1 \%)$ & $8(20.5 \%)$ & 3.54 & 0.08 \\
\hline Specific Phobia & $8(7.3 \%)$ & $7(17.9 \%)$ & 3.63 & 0.07 \\
\hline Generalized Anxiety Disorder & $2(1.8 \%)$ & $4(10.3 \%)$ & 5.31 & 0.04 \\
\hline $\begin{array}{l}\text { MD Features } \\
\text { Age of Onset (years) } \\
\text { Number of Major Depressive Episodes, } n\end{array}$ & -- & $14.9(1.7)$ & & \\
\hline 1 episode & --- & $17(43.6 \%)$ & & \\
\hline 2-3 episodes & --- & $16(41.0 \%)$ & & \\
\hline 3-5 episodes & -- & $3(7.7 \%)$ & & \\
\hline$\geq 6$ episodes & --- & $3(7.7 \%)$ & & \\
\hline Number of symptoms during worst MDE & --- & $5.69(1.1)$ & & \\
\hline
\end{tabular}

Note: SMFQ=Short Mood and Feelings Questionnaire. ${ }^{\S}$ Fagerstrom Test for Nicotine Dependence score ranged 2 (low dependence) to 6 (moderate dependence) with Mode=2, Median=2, and Mean=3. 
Figure 1. Overlap with PGC GWAS of major depression. The 'MD locus' (purple box) represents a region of chromosome 6 extending from 27.7-32.8 Mb found to be significantly associated with depression by Wray et al. (2018). Summary statistics from this study are plotted for the relevant regional markers in the Manhattan plot. Colored ticks represent the 3 DMRs (blue) and 1 VMR (red) located in this region. Individual plots above provide a zoomed-in view of the genomic context surrounding each methylation region and probelevel test statistics. Chromatin states within GM12878 lymphoblastoid cells are indicated by color coding the ChromHMM track.

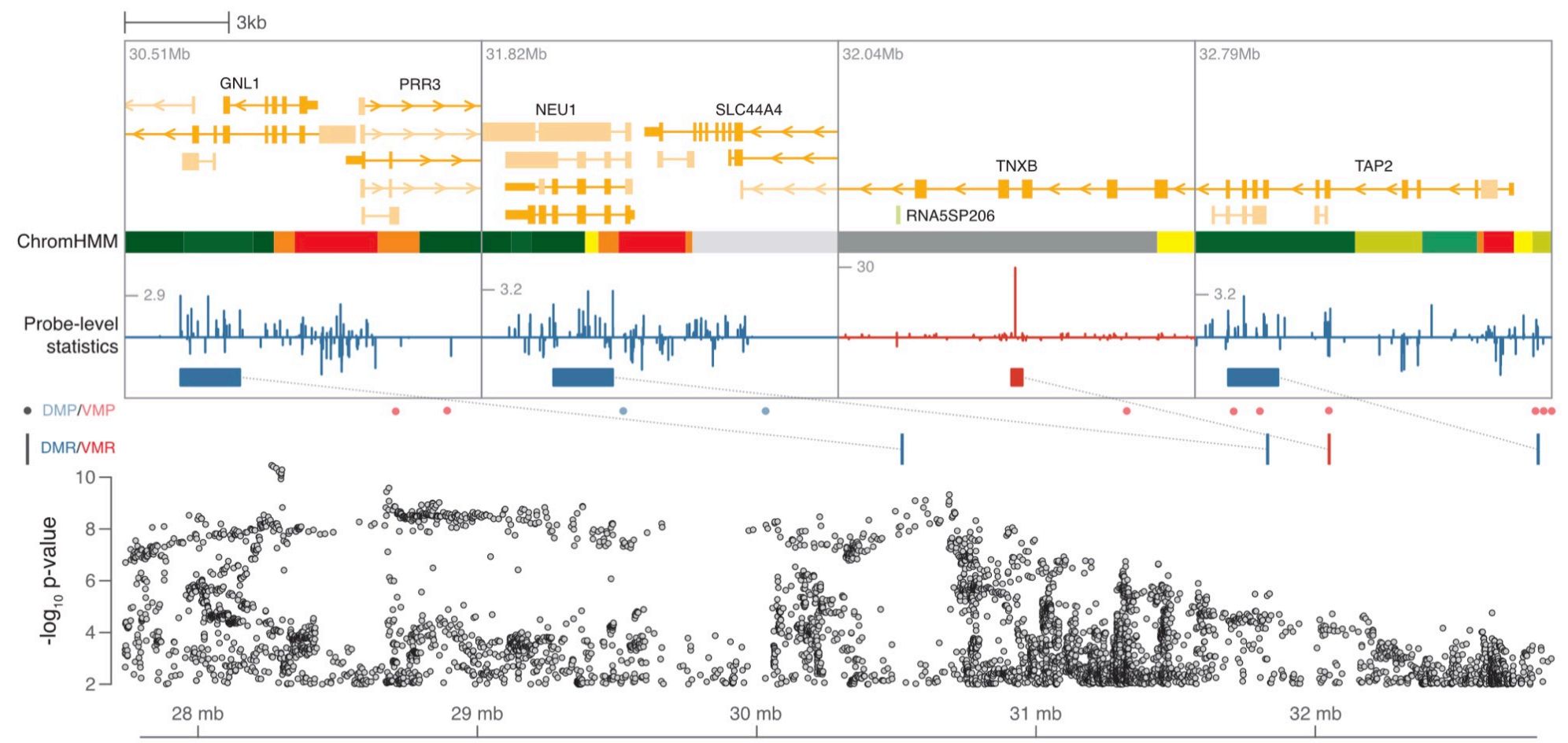

Chromosome 6 
Table 2. Differentially methylated regions (DMRs) where MD affected twins exhibited higher means compared to MD unaffected twins.

\begin{tabular}{ccccccc}
\hline Chromosome & Start & End & Symbol & EntrezID & Number_CpG & Empirical_AUC \\
\hline chr1 & 36787678 & 36789401 & SH3D21 & 79729 & 3 & 3836.3652 \\
chr1 & 221053841 & 221055665 & HLX & 3142 & 4 & 4242.3503 \\
chr2 & 240035107 & 240036791 & HDAC4 & 9759 & 3 & 4057.6444 \\
chr5 & 1090741 & 1092417 & SLC12A7 & 10723 & 4 & 3818.3311 \\
chr5 & 171709917 & 171711524 & UBTD2 & 92181 & 3 & 4070.7302 \\
chr5 & 176936563 & 176938522 & DOK3 & 79930 & 6 & 3826.3018 \\
chr6 & 30519905 & 30521619 & NA & NA & 5 & 3861.8967 \\
chr6 & 31828260 & 31830030 & NA & NA & 4 & 4558.5396 \\
chr6 & 32797253 & 32798887 & NA & NA & 4 & 3849.6722 \\
chr6 & 39281541 & 39283313 & KCNK17 & 89822 & 3 & 4122.0762 \\
chr6 & 146863647 & 146865487 & RAB32 & 10981 & 7 & 4701.7437 \\
chr16 & 2023998 & 2025868 & TBL3 & 10607 & 4 & 4329.8853 \\
chr16 & 58767249 & 58769104 & GOT2 & 2806 & 4 & 4046.9261 \\
chr17 & 46659019 & 46660940 & HOXB3 & 3213 & 4 & 4501.7814 \\
chr17 & 70116185 & 70118162 & SOX9 & 6662 & 4 & 4120.2233 \\
chr19 & 13213428 & 13215387 & LYL1 & 4066 & 3 & 4381.7764 \\
chr21 & 38069321 & 38070994 & NA & NA & 4 & 3892.4767 \\
\hline
\end{tabular}


Table 3. Variably methylated regions (VMRs) where MD affected twins exhibited greater variance compared to MD unaffected twins.

\begin{tabular}{ccccccc} 
Chromosome & Start & End & Symbol & EntrezID & Number_CpG & Empirical_AUC \\
\hline chr3 & 39321449 & 39323539 & CX3CR1 & 1524 & 4 & 5572.9239 \\
chr3 & 46925081 & 46925524 & PTH1R & 5745 & 2 & 5031.1289 \\
chr3 & 170136920 & 170137321 & CLDN11 & 5010 & 2 & 5110.2437 \\
chr6 & 32049516 & 32049825 & NA & NA & 3 & 5038.8717 \\
chr6 & 169284344 & 169287304 & NA & NA & 5 & 5276.0094 \\
chr6 & 170595385 & 170597898 & DLL1 & 28514 & 8 & 5628.6246 \\
chr7 & 157225062 & 157225567 & NA & NA & 2 & 5131.4817 \\
chr10 & 134739746 & 134741032 & CFAP46 & 54777 & 4 & 5667.4646 \\
chr11 & 64510112 & 64513156 & RASGRP2 & 10235 & 7 & 5458.4387 \\
chr17 & 40837037 & 40839469 & CNTNAP1 & 8506 & 4 & 5035.574 \\
\hline
\end{tabular}


Table 4. Gene enrichment analysis summary.

\begin{tabular}{|c|c|c|c|c|c|}
\hline & $\begin{array}{l}\text { Ontology } \\
\text { Category }\end{array}$ & Description & $\begin{array}{l}\text { Gene } \\
\text { Ratio }\end{array}$ & q-value & Gene Symbol \\
\hline GO:0007156 & $\begin{array}{l}\text { Biological } \\
\text { Process }\end{array}$ & $\begin{array}{l}\text { homophilic cell adhesion via } \\
\text { plasma membrane adhesion } \\
\text { molecule }\end{array}$ & 23,568 & 0.00002 & $\begin{array}{l}\text { CDH3, CDH6, PCDH } \alpha \mathrm{C} 1-2, \mathrm{PCDH} \alpha 1-13 \\
\text { PCDH10, PCDH20, PTPRT, CADM1, } \\
\text { PLXNB3, CLSTN2 }\end{array}$ \\
\hline GO:0098742 & $\begin{array}{l}\text { Biological } \\
\text { Process }\end{array}$ & $\begin{array}{l}\text { cell-cell adhesion via plasma- } \\
\text { membrane adhesion molecules }\end{array}$ & 28,568 & 0.00002 & $\begin{array}{l}\text { CDH3, CDH6, PTPRT, CLDN4, CADM1, } \\
\text { GRID2, ITGA5, CLDN11, PLXNB3, } \\
\text { PCDH } \alpha \text { C1-2, PCDH } \alpha 1-13, \text { PCDH20, } \\
\text { PTPRD, CLSTN2 }\end{array}$ \\
\hline GO:0044306 & $\begin{array}{l}\text { Cellular } \\
\text { Function }\end{array}$ & neuron projection terminus & 14,605 & 0.05888 & $\begin{array}{l}\text { BAIAP2, AAK1, CYFIP1, SYT11, PACSIN1, } \\
\text { ILK, PFN2, PNOC, PVALB, DNAJC5, MOB2, } \\
\text { NAPA, BSN, AP3D1 }\end{array}$ \\
\hline GO:0043195 & $\begin{array}{l}\text { Cellular } \\
\text { Function }\end{array}$ & terminal bouton & 9,605 & 0.05888 & $\begin{array}{l}\text { AAK1, CYFIP1, SYT11, ILK, PFN2, PVALB, } \\
\text { DNAJC5, NAPA, AP3D1 }\end{array}$ \\
\hline GO:0033267 & $\begin{array}{l}\text { Cellular } \\
\text { Function }\end{array}$ & axon part & 16,605 & 0.07314 & $\begin{array}{l}\text { AAK1, TRAK1, CYFIP1, SYT11, KIF13B, } \\
\text { AP3M1, NRG1, ILK, PFN2, PVALB, SPG7, } \\
\text { DAGLA, DNAJC5, CNTNAP1, NAPA, } \\
\text { AP3D1 }\end{array}$ \\
\hline GO:0044463 & $\begin{array}{l}\text { Cellular } \\
\text { Function }\end{array}$ & cell projection part & 54,605 & 0.08617 & $\begin{array}{l}\text { AKAP9, RASGRP2, BAIAP2, DCTN2, } \\
\text { IGF2BP1, EHD1, CNGA4, PACRG, EPS8, } \\
\text { ENKUR, SPATA13, AAK1, TRAK1, CYFIP1, } \\
\text { SYT11, KIF13B, TBC1D30, GPR161, } \\
\text { AP3M1, NPHP3, BBS9, GRID2, PACSIN1, } \\
\text { NRG1, ILK, ITGA5, KCNC3, PDE6B, PFN2, } \\
\text { PNOC, SSH1, CFAP46, CCDC40, } \\
\text { PRKAR1B, TTYH1, PTH1R, TENM2, } \\
\text { PVALB, BBS2, MAP2K4, SLC22A5, SPG7, } \\
\text { TIMP2, DAGLA, CA9, JADE1, DNAJC5, } \\
\text { MOB2, CNTNAP1, NAPA, BSN, AP3D1, } \\
\text { DHRS3, RAB28 }\end{array}$ \\
\hline
\end{tabular}




\begin{tabular}{|c|c|c|c|c|c|}
\hline GO:0030424 & $\begin{array}{l}\text { Cellular } \\
\text { Function }\end{array}$ & Axon & 26,605 & 0.08617 & $\begin{array}{l}\text { IGF2BP1, DAB2IP, EPHB2, AAK1, TRAK1, } \\
\text { CYFIP1, SYT11, KIF13B, LDLRAP1, } \\
\text { AP3M1, NRG1, ILK, KCNC3, NF1, PFN2, } \\
\text { SLC17A7, SEMA6A, PVALB, MAP2K4, } \\
\text { SPG7, DAGLA, DNAJC5, CNTNAP1, NAPA, } \\
\text { BSN, AP3D1 }\end{array}$ \\
\hline GO:0098793 & $\begin{array}{l}\text { Cellular } \\
\text { Function }\end{array}$ & Presynapse & 24,605 & 0.08617 & $\begin{array}{l}\text { BAIAP2, AAK1, CYFIP1, SYT11, DMXL2, } \\
\text { AMPH, GRIK4, GRM8, PACSIN1, HIP1, } \\
\text { APBA2, ILK, KCNC3, NF1, SYT17, PFN2, } \\
\text { PNOC, PI4K2A, SLC17A7, PVALB, } \\
\text { DNAJC5, NAPA, BSN, AP3D1 }\end{array}$ \\
\hline
\end{tabular}




\section{SUPPLEMENTAL METHODS}

The primary definition of MD affected status required presence of at least one DSM-5 MDE lasting at least two weeks ${ }^{109}$. MD was considered present if criteria were met at either a definite or a probable level. A definite diagnosis was made when a twin endorsed at least five DSM-5 Criterion A MDE symptoms (e.g., low energy, recurrent thoughts of death, inability to concentrate) of which at least one symptom had to include the presence of low mood and/or anhedonia most of the day, nearly every day for at least two weeks during their worst episode. Probable diagnoses were made when a twin endorsed at least 4 symptoms, one of which had to include the presence of low mood and/or anhedonia most of the day, nearly every day. The use of definite and probable levels allows for the inclusion of twins who may not be currently symptomatic and, therefore, have to rely on retrospective memory to determine their symptom presentation. The use of probable levels of diagnosis also is justified given that twins expressing nearly all symptoms of a MDE are more similar to a case than a control symptomatically and for depressive risk factors ${ }^{110}$. This approach to diagnosis was introduced as part of the Research Diagnostic Criteria and has been applied in many studies ${ }^{111-114}$. To qualify for MD at the definite or probable level, participants also had to report that their depression symptoms caused clinically significant distress or functional impairment (i.e., Criterion C). MD unaffected status was defined as no lifetime diagnosis of MD at the probable or definite threshold. The expanded MD section of the CIDI-SF followed by the lifetime MD algorithm is presented below.

\section{Lifetime Major Depression Diagnostic Questions: Criterion A (MDE Symptoms)}

1. Have you ever had a time in your life when you felt sad, blue, or depressed or two weeks or more in a row? (yes/no)

2. Have you ever had a time in your life lasting two weeks or more when you lost interest in most things like hobbies, work, or activities that usually give you pleasure? (yes/no)

3. During those worst two weeks, did the feelings of sadness or loss of interest usually last all day long, most of the day, about half of the day, or less than half of the day? (All day long, Most of the day, About half of the day, Less than half of the day)

4. Did you feel this way every day, almost every day, or less often during the two weeks? (Every day, Almost every day, Less often)

If a participant responded "yes" to questions 1 OR 2 AND endorsed "all day long" or "most of the day" to question 3 AND responded "every day" or "almost every day" to question 4, they entered the MD section and were queried regarding other DSM-5 Criterion A symptoms of MD (see below).

5. Thinking about those same two weeks, did you feel more tired out or low on energy than is usual for you? (yes/no)

6. Did you gain or lose weight without trying or did you stay about the same? (Gained weight, Lost weight, Gained and lost weight, stayed about the same, I was on a diet)

7. About how much weight did you gain/you lose/your weight change? (numeric response)

8. Did you have more trouble falling asleep or staying asleep than you usually do during those two weeks? (yes/no)

a. Did that happen every night, nearly every night, or less often during those two weeks? (Every night, Nearly every night, Less often)

9. During those two weeks, did you have a lot more trouble concentrating or making decisions than usual? (yes/no) 
10. People sometimes feel down on themselves, no good, or worthless, or have excessive guilt and blame themselves for things. During that two-week period, did you feel this way? (yes/no)

11. Did you think a lot about death - either your own, someone else's, or death in general during those two weeks? (yes/no)

\section{Criterion C (Functional Interference):}

12. Did you ever tell a professional about these problems (such as a medical doctor, psychologist, social worker, counselor, nurse, clergy, or other helping professional)? (yes/no)

13. Did you ever take medication for these problems? (yes/no)

14. How much did these problems interfere with your life or activities - a lot, some, a little, or not at all? (A lot, Some, A little, Not at all)

*additional questions regarding age of onset, timing of last episode, etc. were queried.

\section{Algorithm}

Questions 6 and 7 were recoded so that a response of "Gained weight" or "Gained and lost weight," along with at least a response of 5 pounds in question 7, was coded as endorsement of weight gain/loss. Participants who endorsed question 8 also were presented with question 8a. Sleep symptoms were considered present if a participant answered "Every night" or "Nearly every night" on question 8a. Responses to queries 1, 2, 5, weight gain, sleep symptoms, 9, 10, and 11 were summed as the total number of depression symptoms endorsed during the twin's worst MDE. Participants were deemed to have experienced significant distress if they endorsed question 14 as "a lot" or "some" and/or if they endorsed question 12 or 13 as "yes". MD at the full threshold level was coded positive if the participant endorsed question 1 or 2 along with question 3 as "All day long" or "Most of the day," and question 4 as "Every day" or "Almost every day," and at least 4 other depression symptoms for a total of at least 5 symptoms. MD at the full threshold level also required significant distress. MD was coded positive at the probable level if the participant endorsed question 1 or 2 as well as question 3 ("All day long" / "Most of the day") and question 4 ("Every day" / "Almost every day") and at least 3 other depression symptoms for a total of 4 symptoms. The probable level also required endorsement of significant distress (i.e., endorsed question 12,13 , or 14 as "a lot" or "some").

\section{Exclusionary Criteria}

Participants were not eligible for the current study if they met any of the following criteria: 1) current use of psychotropic medications (e.g., antianxiety/antidepressants) or medications with psychotropic effects (e.g., beta-adrenergic blockers), b) diagnosis of an autism spectrum disorder, c) diagnosis of an intellectual disability, d) diagnosis of a spatial learning disorder, or prior testing indicating an IQ below 70, e) seizure without a clear and resolved etiology, f) current or past episodes of psychosis, g) serious, not stabilized illness (e.g., liver, kidney, gastrointestinal, respiratory, cardiovascular, endocrinologic, neurologic, immunologic, or blood disease), h) inadequate production of human growth hormone, i) sensory integration disorder, j) congenital adrenal hyperplasia, k) adrenal inefficiency, I) deaf with bicochlear implants, $\mathrm{m}$ ) cancer (current or past diagnosis), and $n$ ) pregnancy (current or lifetime). If only one twin from the twin pair met any of the exclusionary criteria, the whole pair was excluded.

\section{Zygosity}

Zygosity status (monozygotic [MZ] versus dizygotic [DZ]) for adolescent twins (age $\leq 17$ ) was determined based on parent-report about physical similarities between twins. Adult twins (age $\geq 18$ ) not accompanied by a parent/legal guardian completed the zygosity questionnaire 
about themselves. Prior research has demonstrated high validity for this zygosity assessment as compared to blood ${ }^{115}$ and DNA evaluations of zygosity ${ }^{116}$. MZ zygosity based on questionnaire assessment was confirmed using 65 SNP control probes included on the Infinium HumanMethylation450 (450K) array to verify sample identity. The control probes target polymorphic sequences, and values for each probe cluster into three groups corresponding to genotype. Together, the control probes provide strong support for validating zygosity. Only data from twins confirmed to be $\mathrm{MZ}$ were included in analyses.

\section{Genome-wide DNAm Measurement and Processing}

Genomic DNA was isolated from whole blood according to standard methods using the Puregene DNA Isolation Kit (Qiagen). An aliquot of 1 microgram DNA per subject was processed by HudsonAlpha Institute for Biotechnology for bisulfite conversion (Zymo Research EZ Methylation Kit) and genome-wide methylation assayed on the Infinium Human Methylation 450K BeadChip microarray, which interrogates 485,764 features. Twin pairs were localized to the same slide to minimize any potential artifactual differences in DNAm patterns due to batch effects.

Details of the $450 \mathrm{~K}$ microarray have been previously described ${ }^{117}$, and raw data processing was performed according to best practices reported in recent publications ${ }^{50,118}$. Intensity values from the scanned arrays were processed using the minfi Bioconductor package $^{119}$ in the $R$ programming environment ( $R$ Development Core Team 2015). Confirmation of self-reported race was made by sample clustering derived from principal components estimated from ancestry informative probes ${ }^{120}$.

Quality was assessed both quantitatively and visually to identify deviant samples ${ }^{119}$. Beta values were derived as the ratio of the methylated probe intensity to the sum of the methylated and unmethylated probe intensities ${ }^{121}$. Beta value density plots from each array were inspected to tag poor performing arrays based on a large deviation from the rest of the samples. Probes were filtered if they had a detection P-value of greater than 0.01 in at least $10 \%$ of samples or if they have been previously identified as cross-hybridizing ${ }^{122}$ leaving a total of 455,828 probes to analyze. Quantile normalization adapted to DNAm arrays ${ }^{123}$ was applied to adjust the distribution of type I and II probes to the final set of screened sample arrays and probes.

For all statistical tests, beta values were transformed using the $M$-value procedure to promote normality and calculated as a logit transformation of the methylated and unmethylated intensity ratio along with an added constant to offset potentially small values ${ }^{121}$. Correlations between major experimental factors and the top 10 principal components of $M$-values across all arrays were inspected to identify extraneous structure that may account for any batch effects ${ }^{124}$. ComBat was used to remove average differences across arrays due to slide groupings ${ }^{125}$. Blood cell proportions were inferred for each sample to account for cellular heterogeneity ${ }^{126}$. 
Supplemental Table 1. Statistical contrasts fit to estimate the degrees of association between MD affected/unaffected status and genome-wide DNA methylation markers.

\begin{tabular}{lcccccc}
\hline & $\begin{array}{c}\text { Concord- } \\
\text { ant MD T1 }\end{array}$ & $\begin{array}{c}\text { Concordant MD } \\
\text { T2 }\end{array}$ & $\begin{array}{c}\text { Discordant } \\
\text { T1 }\end{array}$ & $\begin{array}{c}\text { Discord- } \\
\text { ant T2 }\end{array}$ & $\begin{array}{c}\text { Concord- } \\
\text { ant Healthy } \\
\text { T1 }\end{array}$ & $\begin{array}{c}\text { Concordant } \\
\text { Healthy T2 }\end{array}$ \\
\hline contrast 1 & -1 & -1 & -1 & 1 & 1 & 1 \\
contrast 2 & -1 & -1 & 2 & 0 & 0 & 0 \\
contrast 3 & 0 & 0 & 0 & 2 & -1 & -1 \\
contrast 4 & -1 & 1 & 0 & 0 & 0 & 0 \\
contrast 5 & 0 & 0 & 0 & 0 & -1 & 1 \\
\hline
\end{tabular}

Note: T1 = Twin 1 and T2 = Twin 2. 
Supplemental Figure 1. Bivariate distribution of DNAm probes, where one twin pair is discordant for a history of MD and the other is concordant healthy. A twin member from the discordant pair and the concordant healthy pair is then crossed in the upper right and lower left panels, creating "non-MZ" pairs. This figure shows that the bivariate distribution of DNAm marks differ between the concordant healthy and discordant twins, with the discordant pair showing greater variation between twins. The lower left panel, which represents an unrelated case-control, illustrates the substantial increase in variance, underscoring the utility of the co-twin control design to study environmental risk.
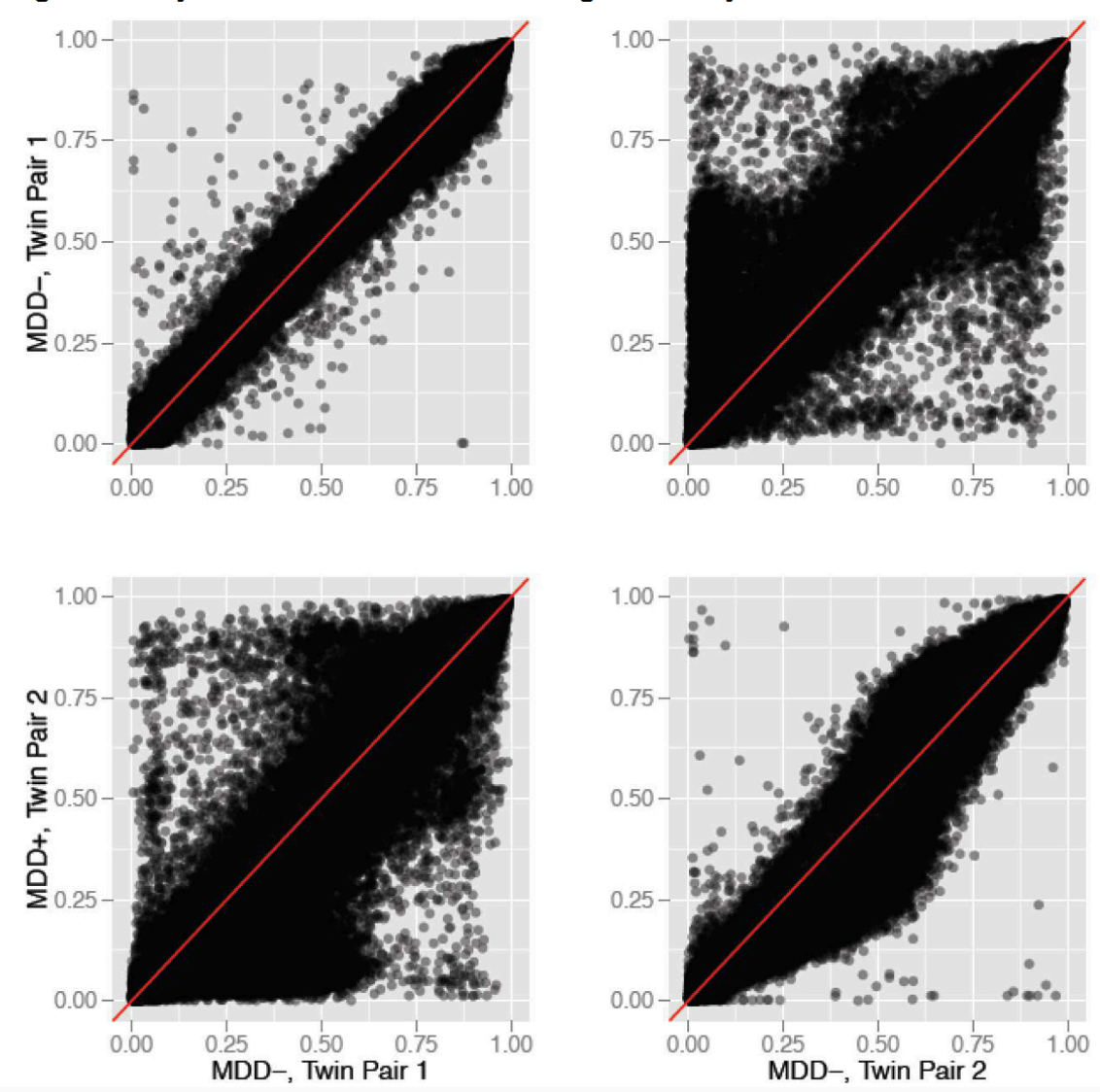


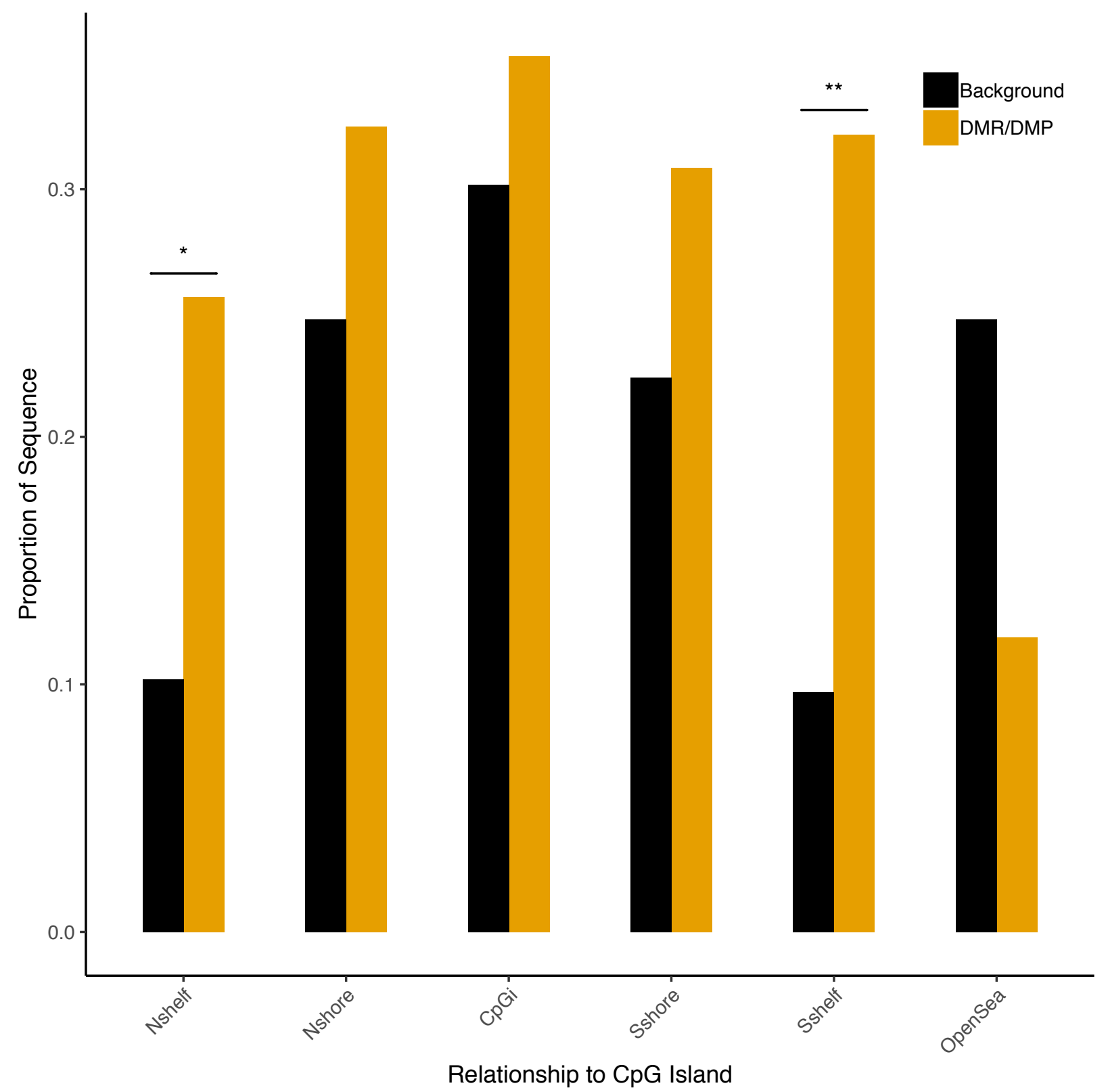





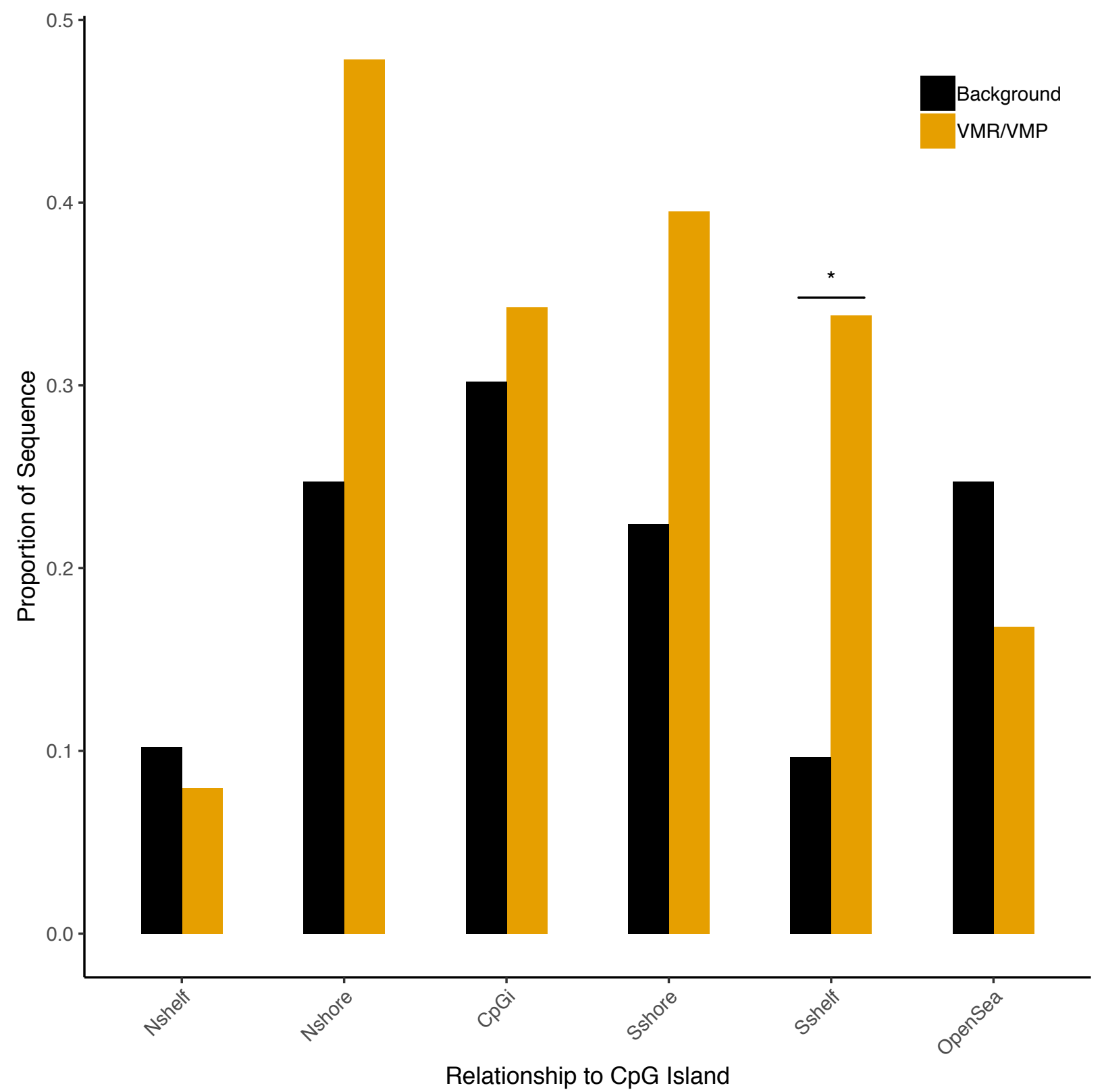




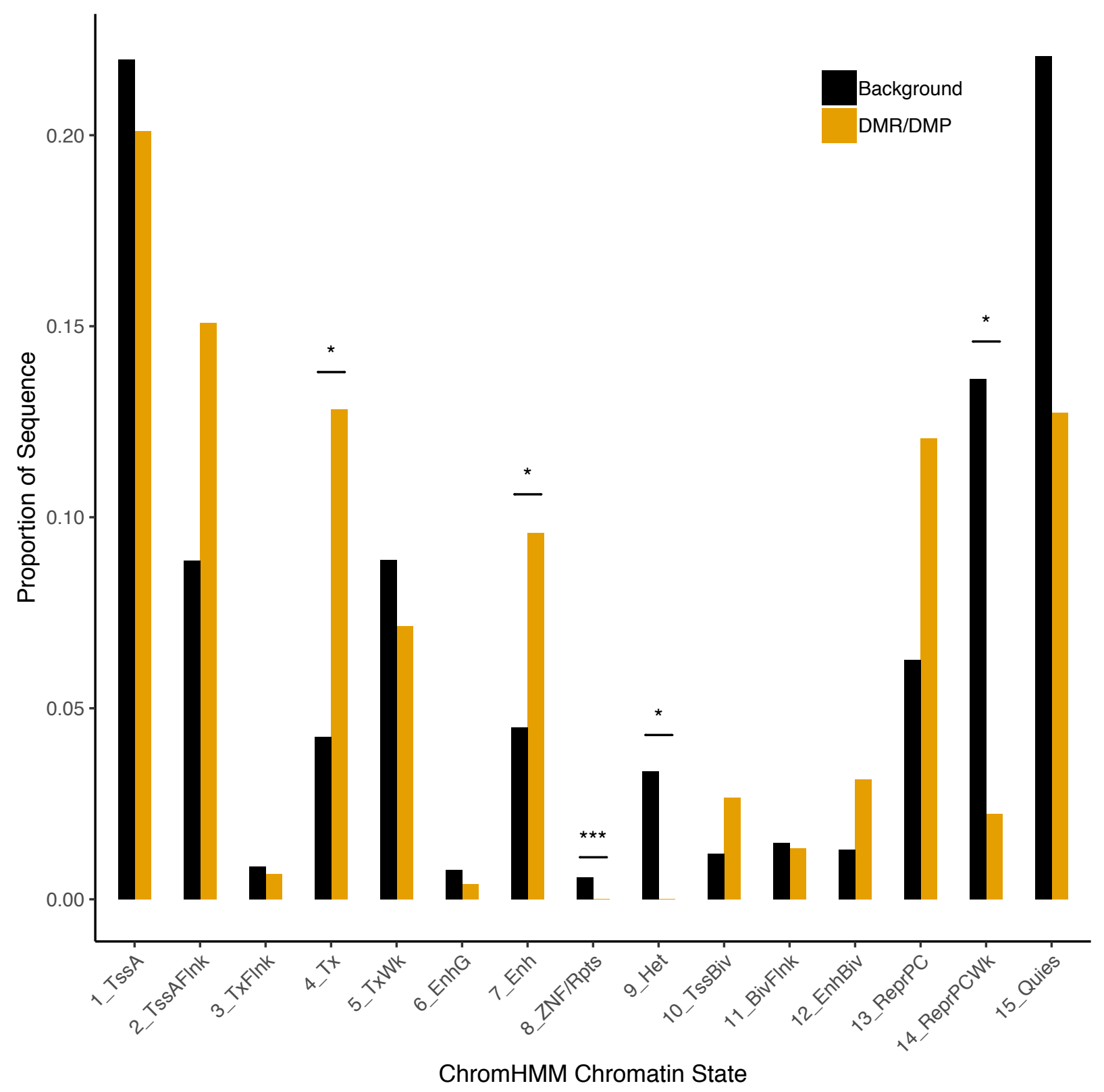




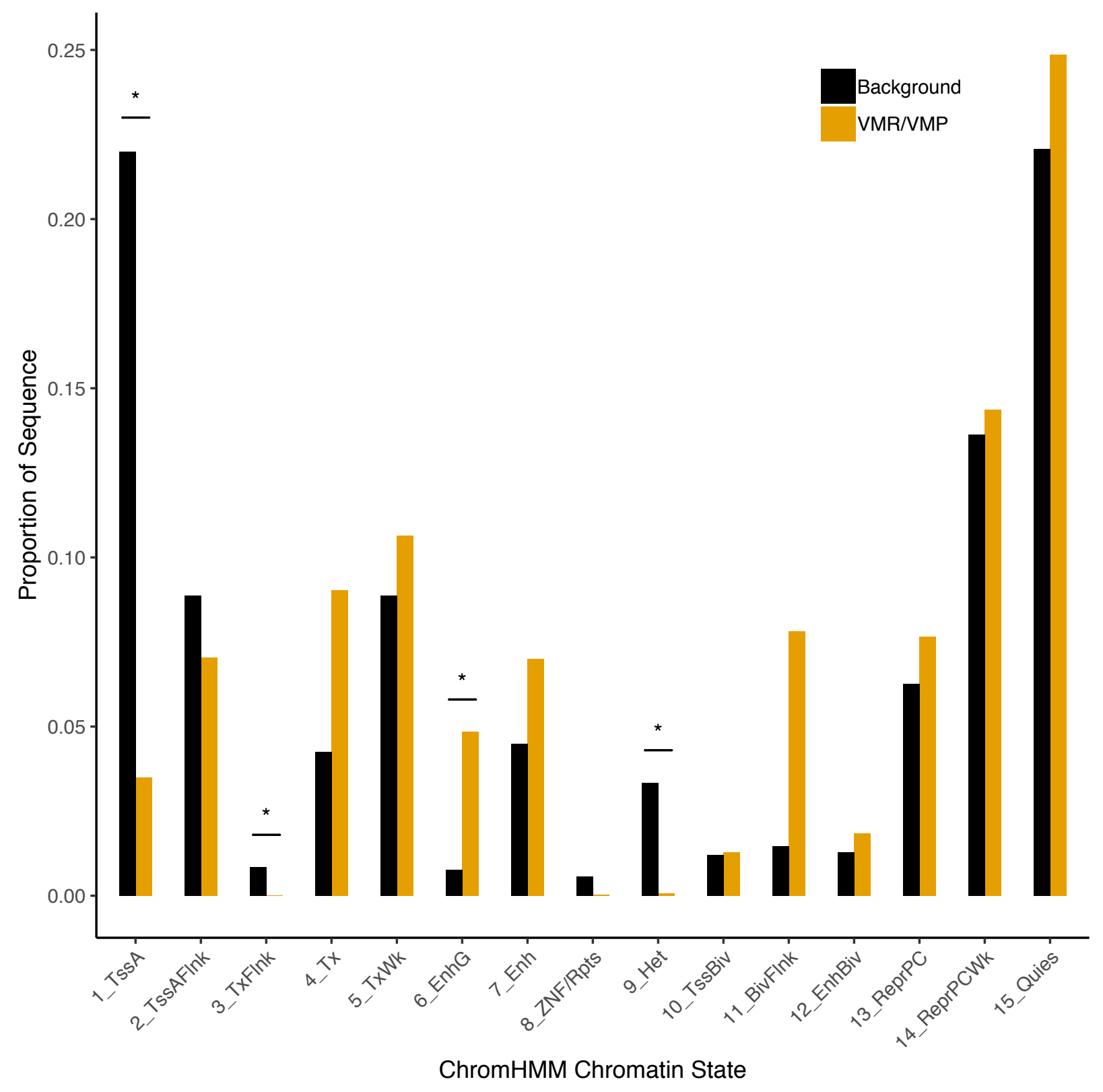




\section{Supplemental Table 2. DMP significant gene/promoter hits identified in the MD affected} versus MD unaffected contrast.

\begin{tabular}{|c|c|c|c|}
\hline entrez & Symbol & dmp.gene & dmp.prom \\
\hline 1001 & $\mathrm{CDH} 3$ & NA & 1 \\
\hline 100126332 & MIR943 & NA & 1 \\
\hline 100129845 & PCOLCE-AS1 & NA & 1 \\
\hline 100302152 & MIR548N & 1 & NA \\
\hline 100422962 & MIR4281 & NA & 1 \\
\hline 100506866 & TTN-AS1 & 1 & NA \\
\hline 100526737 & RBM14-RBM4 & 1 & NA \\
\hline 100528018 & ARL2-SNX15 & 1 & NA \\
\hline 100616144 & MIR548AN & 1 & NA \\
\hline 100616190 & MIR548O2 & 1 & NA \\
\hline 100616266 & MIR4733 & NA & 1 \\
\hline 10458 & BAIAP2 & 1 & NA \\
\hline 10540 & DCTN2 & 1 & 1 \\
\hline 10555 & AGPAT2 & 1 & NA \\
\hline 10560 & SLC19A2 & 1 & 1 \\
\hline 10642 & IGF2BP1 & 1 & NA \\
\hline 10659 & CELF2 & 1 & 1 \\
\hline 10718 & NRG3 & 1 & NA \\
\hline 10981 & RAB32 & 1 & NA \\
\hline 11167 & FSTL1 & 1 & 1 \\
\hline 117248 & GALNT15 & 1 & NA \\
\hline 125061 & AFMID & 1 & 1 \\
\hline 125488 & TTC39C & 1 & 1 \\
\hline 126917 & IFFO2 & 1 & NA \\
\hline 133121 & ENPP6 & 1 & NA \\
\hline 135138 & PACRG & 1 & NA \\
\hline 137902 & PXDNL & 1 & 1 \\
\hline 1456 & CSNK1G3 & 1 & NA \\
\hline 151278 & CCDC140 & 1 & NA \\
\hline 153339 & TMEM167A & NA & 1 \\
\hline 154043 & CNKSR3 & 1 & NA \\
\hline 161003 & STOML3 & NA & 1 \\
\hline 171425 & CLYBL & 1 & NA \\
\hline 1745 & DLX1 & 1 & NA \\
\hline 1876 & E2F6 & NA & 1 \\
\hline 1877 & E4F1 & 1 & NA \\
\hline 1880 & GPR183 & NA & 1 \\
\hline
\end{tabular}




\begin{tabular}{|c|c|c|c|}
\hline 2059 & EPS8 & 1 & NA \\
\hline 2070 & EYA4 & 1 & 1 \\
\hline 2173 & FABP7 & 1 & NA \\
\hline 221061 & FAM171A1 & 1 & NA \\
\hline 2256 & FGF11 & NA & 1 \\
\hline 22821 & RASA3 & 1 & NA \\
\hline 22854 & NTNG1 & 1 & NA \\
\hline 22986 & SORCS3 & 1 & NA \\
\hline 23065 & EMC1 & 1 & NA \\
\hline 23108 & RAP1GAP2 & 1 & NA \\
\hline 23150 & FRMD4B & 1 & NA \\
\hline 23344 & ESYT1 & NA & 1 \\
\hline 23484 & LEPROTL1 & NA & 1 \\
\hline 253314 & EIF4E1B & NA & 1 \\
\hline 25766 & PRPF40B & 1 & NA \\
\hline 25782 & RAB3GAP2 & 1 & NA \\
\hline 26034 & IPCEF1 & 1 & NA \\
\hline 26099 & SZRD1 & 1 & NA \\
\hline 27031 & NPHP3 & 1 & NA \\
\hline 27241 & BBS9 & NA & 1 \\
\hline 273 & AMPH & 1 & NA \\
\hline 28232 & SLCO3A1 & NA & 1 \\
\hline 311 & ANXA11 & NA & 1 \\
\hline 337867 & UBAC2 & 1 & NA \\
\hline 348808 & NPHP3-AS1 & NA & 1 \\
\hline 3595 & IL12RB2 & NA & 1 \\
\hline 390598 & SKOR1 & 1 & NA \\
\hline 3983 & ABLIM1 & 1 & 1 \\
\hline 404663 & LINC01194 & 1 & NA \\
\hline 404665 & CACTIN-AS1 & NA & 1 \\
\hline 4088 & SMAD3 & 1 & NA \\
\hline 4299 & AFF1 & 1 & NA \\
\hline 439990 & LINC00857 & NA & 1 \\
\hline 440695 & ETV3L & 1 & NA \\
\hline 4430 & MY01B & 1 & NA \\
\hline 463 & ZFHX3 & 1 & NA \\
\hline 4682 & NUBP1 & NA & 1 \\
\hline 4763 & NF1 & 1 & NA \\
\hline 50515 & CHST11 & NA & 1 \\
\hline 51154 & MRTO4 & NA & 1 \\
\hline
\end{tabular}




\begin{tabular}{|c|c|c|c|}
\hline 5118 & PCOLCE & 1 & NA \\
\hline 51527 & GSKIP & NA & 1 \\
\hline 51760 & SYT17 & NA & 1 \\
\hline 5368 & PNOC & 1 & NA \\
\hline 54472 & TOLLIP & 1 & NA \\
\hline 54715 & RBFOX1 & 1 & NA \\
\hline 55002 & TMCO3 & 1 & NA \\
\hline 55076 & TMEM45A & 1 & NA \\
\hline 55102 & ATG2B & 1 & NA \\
\hline 574408 & MIR329-1 & NA & 1 \\
\hline 574409 & MIR329-2 & NA & 1 \\
\hline 57451 & TENM2 & 1 & NA \\
\hline 57537 & SORCS2 & 1 & NA \\
\hline 57552 & NCEH1 & 1 & NA \\
\hline 5912 & RAP2B & 1 & NA \\
\hline 5915 & RARB & 1 & NA \\
\hline 5936 & RBM4 & NA & 1 \\
\hline 596 & BCL2 & 1 & 1 \\
\hline 64084 & CLSTN2 & 1 & NA \\
\hline 6416 & MAP2K4 & 1 & NA \\
\hline 6423 & SFRP2 & NA & 1 \\
\hline 64478 & CSMD1 & 1 & NA \\
\hline 647288 & CTAGE11P & NA & 1 \\
\hline 6620 & SNCB & 1 & NA \\
\hline 670 & BPHL & 1 & NA \\
\hline 6915 & TBXA2R & 1 & 1 \\
\hline 7083 & TK1 & NA & 1 \\
\hline 7273 & TTN & 1 & NA \\
\hline 7441 & VPREB1 & NA & 1 \\
\hline 7469 & NELFA & 1 & 1 \\
\hline 7518 & XRCC4 & 1 & 1 \\
\hline 752 & FMNL1 & 1 & NA \\
\hline 7520 & XRCC5 & 1 & 1 \\
\hline 768212 & MIR758 & 1 & 1 \\
\hline 7813 & EVI5 & 1 & NA \\
\hline 79570 & NKAIN1 & 1 & NA \\
\hline 79740 & ZBBX & NA & 1 \\
\hline 80028 & FBXL18 & 1 & NA \\
\hline 80331 & DNAJC5 & 1 & NA \\
\hline 84717 & HDGFL2 & NA & 1 \\
\hline
\end{tabular}


bioRxiv preprint doi: https://doi.org/10.1101/422345; this version posted November 1, 2018. The copyright holder for this preprint (which was not certified by peer review) is the author/funder, who has granted bioRxiv a license to display the preprint in perpetuity. It is made available under aCC-BY-NC-ND 4.0 International license.

\begin{tabular}{rlcc}
84892 & POMGNT2 & 1 & 1 \\
84953 & MICALCL & NA & 1 \\
8802 & SUCLG1 & 1 & 1 \\
8817 & FGF18 & NA & 1 \\
8874 & ARHGEF7 & 1 & NA \\
8924 & HERC2 & 1 & NA \\
91522 & COL23A1 & NA & 1 \\
92181 & UBTD2 & 1 & NA \\
9276 & COPB2 & NA & 1 \\
9496 & TBX4 & 1 & 1 \\
9671 & WSCD2 & NA & 1 \\
9727 & RAB11FIP3 & 1 & NA \\
9844 & ELMO1 & 1 & 1 \\
995 & CDC25C & 1 & 1 \\
\hline
\end{tabular}


Supplemental Table 3. VMP significant gene/promoter hits identified in the MD affected versus MD unaffected contrast.

\begin{tabular}{|c|c|c|c|}
\hline entrez & symbol & vmp.gene & vmp.prom \\
\hline 100128264 & HTR5A-AS1 & 1 & NA \\
\hline 100128568 & LOC100128568 & 1 & NA \\
\hline 100131213 & ZNF503-AS2 & 1 & 1 \\
\hline 100132406 & NBPF10 & 1 & NA \\
\hline 100132677 & BSN-DT & 1 & 1 \\
\hline 100133612 & LINC01134 & 1 & NA \\
\hline 100189589 & DCTN1-AS1 & 1 & NA \\
\hline 100271715 & ARHGEF33 & 1 & NA \\
\hline 100288142 & NBPF20 & 1 & NA \\
\hline 100302197 & MIR1306 & NA & 1 \\
\hline 100302224 & MIR2110 & NA & 1 \\
\hline 100316904 & SAP25 & 1 & NA \\
\hline 1004 & CDH6 & 1 & NA \\
\hline 100500860 & MIR3618 & NA & 1 \\
\hline 100526835 & FPGT-TNNI3K & 1 & NA \\
\hline 100529261 & CHURC1-FNTB & 1 & NA \\
\hline 100532732 & MSH5-SAPCD1 & NA & 1 \\
\hline 100533179 & UBE2F-SCLY & NA & 1 \\
\hline 100533184 & ARHGAP19-SLIT1 & 1 & NA \\
\hline 100534589 & HOXA10-HOXA9 & 1 & NA \\
\hline 100616250 & MIR3960 & 1 & 1 \\
\hline 10142 & AKAP9 & NA & 1 \\
\hline 10172 & ZNF256 & NA & 1 \\
\hline 10194 & TSHZ1 & NA & 1 \\
\hline 10195 & ALG3 & NA & 1 \\
\hline 102 & ADAM10 & 1 & NA \\
\hline 10201 & NME6 & 1 & NA \\
\hline 10207 & PATJ & 1 & NA \\
\hline 10217 & CTDSPL & 1 & NA \\
\hline 1025 & CDK9 & NA & 1 \\
\hline 10351 & ABCA8 & 1 & NA \\
\hline 10480 & EIF3M & 1 & 1 \\
\hline 10499 & NCOA2 & 1 & NA \\
\hline 10500 & SEMA6C & NA & 1 \\
\hline 10516 & FBLN5 & 1 & 1 \\
\hline 10522 & DEAF1 & 1 & NA \\
\hline 10557 & RPP38 & 1 & NA \\
\hline
\end{tabular}




\begin{tabular}{|c|c|c|c|}
\hline 10667 & FARS2 & 1 & NA \\
\hline 10693 & ССТ6B & 1 & NA \\
\hline 10938 & EHD1 & 1 & 1 \\
\hline 11100 & HNRNPUL1 & 1 & 1 \\
\hline 11122 & PTPRT & 1 & NA \\
\hline 11129 & CLASRP & 1 & NA \\
\hline 11176 & BAZ2A & 1 & 1 \\
\hline 11211 & FZD10 & NA & 1 \\
\hline 11277 & TREX1 & 1 & 1 \\
\hline 113091 & PTH2 & 1 & NA \\
\hline 113791 & PIK3IP1 & 1 & 1 \\
\hline 1141 & CHRNB2 & 1 & NA \\
\hline 114815 & SORCS1 & 1 & NA \\
\hline 114818 & KLHL29 & 1 & 1 \\
\hline 114827 & FHAD1 & 1 & NA \\
\hline 115817 & DHRS1 & NA & 1 \\
\hline 116729 & PPP1R27 & 1 & NA \\
\hline 116987 & AGAP1 & 1 & NA \\
\hline 118424 & UBE2J2 & 1 & NA \\
\hline 1186 & CLCN7 & 1 & NA \\
\hline 1213 & CLTC & NA & 1 \\
\hline 124093 & CCDC78 & NA & 1 \\
\hline 124401 & ANKS3 & 1 & NA \\
\hline 124637 & CYB5D1 & 1 & NA \\
\hline 1262 & CNGA4 & NA & 1 \\
\hline 126374 & WTIP & NA & 1 \\
\hline 126868 & MAB21L3 & NA & 1 \\
\hline 1284 & COL4A2 & 1 & NA \\
\hline 129293 & TRABD2A & NA & 1 \\
\hline 129787 & TMEM18 & 1 & 1 \\
\hline 131566 & DCBLD2 & 1 & 1 \\
\hline 131965 & METTL6 & 1 & 1 \\
\hline 132 & ADK & NA & 1 \\
\hline 132851 & SPATA4 & 1 & 1 \\
\hline 133015 & PACRGL & 1 & NA \\
\hline 134121 & C5orf49 & 1 & NA \\
\hline 134145 & FAM173B & NA & 1 \\
\hline 1364 & CLDN4 & NA & 1 \\
\hline 1369 & CPN1 & 1 & NA \\
\hline 1395 & CRHR2 & 1 & NA \\
\hline
\end{tabular}




\begin{tabular}{|c|c|c|c|}
\hline 140739 & UBE2F & NA & 1 \\
\hline 140828 & LINC00261 & 1 & NA \\
\hline 144481 & SOCS2-AS1 & NA & 1 \\
\hline 1446 & CSN1S1 & 1 & 1 \\
\hline 144699 & FBXL14 & NA & 1 \\
\hline 145376 & PPP1R36 & 1 & 1 \\
\hline 146050 & ZSCAN29 & NA & 1 \\
\hline 146712 & B3GNTL1 & 1 & NA \\
\hline 148014 & TTC9B & NA & 1 \\
\hline 148362 & BROX & 1 & 1 \\
\hline 148398 & SAMD11 & 1 & 1 \\
\hline 148741 & ANKRD35 & 1 & NA \\
\hline 148753 & FAM163A & 1 & 1 \\
\hline 149233 & IL23R & 1 & NA \\
\hline 150538 & SATB2-AS1 & 1 & NA \\
\hline 152992 & TRMT44 & 1 & 1 \\
\hline 153090 & DAB2IP & 1 & NA \\
\hline 153768 & PRELID2 & NA & 1 \\
\hline 1592 & CYP26A1 & 1 & 1 \\
\hline 1613 & DAPK3 & 1 & 1 \\
\hline 161424 & NOP9 & NA & 1 \\
\hline 162461 & TMEM92 & NA & 1 \\
\hline 1639 & DCTN1 & 1 & NA \\
\hline 168090 & C6orf118 & 1 & NA \\
\hline 1838 & DTNB & 1 & NA \\
\hline 1850 & DUSP8 & NA & 1 \\
\hline 1854 & DUT & NA & 1 \\
\hline 1890 & TYMP & 1 & 1 \\
\hline 199990 & FAAP20 & 1 & NA \\
\hline 2000 & ELF4 & NA & 1 \\
\hline 2003 & ELK2AP & 1 & NA \\
\hline 200424 & TET3 & 1 & NA \\
\hline 201514 & ZNF584 & 1 & 1 \\
\hline 2035 & EPB41 & 1 & NA \\
\hline 2048 & EPHB2 & 1 & NA \\
\hline 204851 & HIPK1 & 1 & 1 \\
\hline 210 & ALAD & NA & 1 \\
\hline 2104 & ESRRG & 1 & NA \\
\hline 2120 & ETV6 & NA & 1 \\
\hline 2130 & EWSR1 & 1 & 1 \\
\hline
\end{tabular}




\begin{tabular}{|c|c|c|c|}
\hline 219670 & ENKUR & 1 & 1 \\
\hline 220064 & ORAOV1 & NA & 1 \\
\hline 220359 & TIGD3 & 1 & 1 \\
\hline 221060 & C10orf111 & NA & 1 \\
\hline 221150 & SKA3 & 1 & NA \\
\hline 221178 & SPATA13 & 1 & NA \\
\hline 222643 & UNC5CL & 1 & 1 \\
\hline 225 & ABCD2 & 1 & 1 \\
\hline 2253 & FGF8 & 1 & NA \\
\hline 22801 & ITGA11 & 1 & NA \\
\hline 22848 & AAK1 & 1 & NA \\
\hline 22889 & KHDC4 & 1 & \\
\hline 22906 & TRAK1 & 1 & 1 \\
\hline 22928 & SEPHS2 & 1 & 1 \\
\hline 22948 & ССT5 & 1 & NA \\
\hline 22950 & SLC4A1AP & 1 & 1 \\
\hline 22996 & TTC39A & 1 & NA \\
\hline 23001 & WDFY3 & 1 & NA \\
\hline 23033 & DOPEY1 & NA & 1 \\
\hline 23126 & POGZ & 1 & NA \\
\hline 23143 & LRCH1 & 1 & NA \\
\hline 23179 & RGL1 & 1 & NA \\
\hline 23191 & CYFIP1 & NA & 1 \\
\hline 23208 & SYT11 & 1 & NA \\
\hline 2326 & FMO1 & 1 & NA \\
\hline 23266 & ADGRL2 & 1 & NA \\
\hline 2327 & FMO2 & 1 & NA \\
\hline 23294 & ANKS1A & 1 & NA \\
\hline 23303 & KIF13B & 1 & NA \\
\hline 23312 & DMXL2 & 1 & NA \\
\hline 23314 & SATB2 & NA & 1 \\
\hline 23329 & TBC1D30 & NA & 1 \\
\hline 23352 & UBR4 & NA & 1 \\
\hline 23353 & SUN1 & 1 & NA \\
\hline 23378 & RRP8 & NA & 1 \\
\hline 23406 & COTL1 & 1 & NA \\
\hline 2342 & FNTB & NA & I \\
\hline 23432 & GPR161 & 1 & 1 \\
\hline 23492 & CBX7 & NA & 1 \\
\hline 23554 & TSPAN12 & NA & \\
\hline
\end{tabular}




\begin{tabular}{|c|c|c|c|}
\hline 23705 & CADM1 & 1 & NA \\
\hline 238 & ALK & 1 & NA \\
\hline 24142 & NAT6 & 1 & 1 \\
\hline 254394 & MCM9 & 1 & 1 \\
\hline 2548 & GAA & 1 & NA \\
\hline 256356 & GK5 & NA & 1 \\
\hline 25807 & RHBDD3 & NA & 1 \\
\hline 259217 & HSPA12A & 1 & NA \\
\hline 25939 & SAMHD1 & NA & 1 \\
\hline 25941 & TPGS2 & 1 & NA \\
\hline 25956 & SEC31B & 1 & NA \\
\hline 26057 & ANKRD17 & 1 & NA \\
\hline 26092 & TOR1AIP1 & 1 & NA \\
\hline 26119 & LDLRAP1 & 1 & NA \\
\hline 26136 & TES & 1 & NA \\
\hline 26207 & PITPNC1 & 1 & NA \\
\hline 26520 & TIMM9 & 1 & NA \\
\hline 26801 & SNORD48 & NA & 1 \\
\hline 26828 & RNU5F-1 & 1 & NA \\
\hline 26974 & ZNF285 & NA & 1 \\
\hline 26985 & AP3M1 & NA & 1 \\
\hline 26995 & TRUB2 & NA & 1 \\
\hline 271 & AMPD2 & 1 & 1 \\
\hline 27102 & EIF2AK1 & 1 & NA \\
\hline 27229 & TUBGCP4 & NA & 1 \\
\hline 27237 & ARHGEF 16 & 1 & NA \\
\hline 27243 & CHMP2A & NA & 1 \\
\hline 27255 & CNTN6 & 1 & NA \\
\hline 27327 & TNRC6A & 1 & 1 \\
\hline 27346 & TMEM97 & NA & 1 \\
\hline 2774 & GNAL & 1 & NA \\
\hline 2788 & GNG7 & 1 & NA \\
\hline 283102 & KRT8P41 & NA & 1 \\
\hline 283554 & GPR137C & NA & 1 \\
\hline 283856 & LOC283856 & 1 & NA \\
\hline 284069 & FAM171A2 & NA & 1 \\
\hline 284098 & PIGW & 1 & NA \\
\hline 284273 & ZADH2 & 1 & NA \\
\hline 284352 & PPP1R37 & NA & 1 \\
\hline 285116 & AHCTF1P1 & 1 & NA \\
\hline
\end{tabular}




\begin{tabular}{|c|c|c|c|}
\hline 28514 & DLL1 & 1 & NA \\
\hline 285590 & SH3PXD2B & 1 & NA \\
\hline 285593 & LOC285593 & 1 & NA \\
\hline 2895 & GRID2 & 1 & NA \\
\hline 28974 & C19orf53 & 1 & NA \\
\hline 2900 & GRIK4 & 1 & NA \\
\hline 2918 & GRM8 & 1 & 1 \\
\hline 29993 & PACSIN1 & NA & 1 \\
\hline 3084 & NRG1 & 1 & NA \\
\hline 3092 & HIP1 & 1 & NA \\
\hline 3106 & HLA-B & NA & 1 \\
\hline 3148 & HMGB2 & NA & 1 \\
\hline 317751 & MESTIT1 & NA & 1 \\
\hline 3185 & HNRNPF & 1 & 1 \\
\hline 3205 & HOXA9 & 1 & NA \\
\hline 321 & APBA2 & 1 & NA \\
\hline 330 & BIRC3 & NA & 1 \\
\hline 334 & APLP2 & NA & 1 \\
\hline 3361 & HTR5A & 1 & NA \\
\hline 337968 & KRTAP6-3 & NA & 1 \\
\hline 338651 & KRTAP5-AS1 & 1 & 1 \\
\hline 339 & APOBEC1 & 1 & NA \\
\hline 339416 & ANKRD45 & 1 & NA \\
\hline 342977 & NANOS3 & 1 & NA \\
\hline 343099 & CCDC18 & 1 & NA \\
\hline 347689 & SOX2-OT & 1 & NA \\
\hline 348262 & MCRIP1 & NA & 1 \\
\hline 350383 & GPR142 & NA & 1 \\
\hline 3611 & ILK & 1 & 1 \\
\hline 3678 & ITGA5 & 1 & 1 \\
\hline 3707 & ITPKB & 1 & $\mathrm{NA}$ \\
\hline 3720 & JARID2 & 1 & 1 \\
\hline 3748 & KCNC3 & 1 & 1 \\
\hline 374928 & ZNF773 & NA & 1 \\
\hline 375033 & PEAR1 & 1 & NA \\
\hline 375196 & LOC375196 & NA & 1 \\
\hline 375387 & NRROS & 1 & NA \\
\hline 376267 & RAB15 & NA & 1 \\
\hline 376497 & SLC27A1 & 1 & NA \\
\hline 3784 & KCNQ1 & 1 & NA \\
\hline
\end{tabular}




\begin{tabular}{|c|c|c|}
\hline 38 & ACAT1 & 1 \\
\hline 388394 & RPRML & NA \\
\hline 389337 & ARHGEF37 & NA \\
\hline 390010 & NKX1-2 & 1 \\
\hline 3930 & LBR & NA \\
\hline 3932 & LCK & 1 \\
\hline 399665 & FAM102A & 1 \\
\hline 4004 & LMO1 & 1 \\
\hline 401145 & CCSER1 & 1 \\
\hline 401898 & ZNF833P & 1 \\
\hline 404093 & CUEDC1 & NA \\
\hline 407015 & MIR26A1 & NA \\
\hline 4148 & MATN3 & NA \\
\hline 4176 & MCM7 & 1 \\
\hline 4223 & MEOX2 & 1 \\
\hline 4232 & MEST & 1 \\
\hline 4240 & MFGE8 & 1 \\
\hline 4297 & KMT2A & NA \\
\hline 4329 & ALDH6A1 & NA \\
\hline 440119 & FZD10-DT & 1 \\
\hline 4430 & MYO1B & 1 \\
\hline 475 & ATOX1 & NA \\
\hline 4750 & NEK1 & 1 \\
\hline 4782 & NFIC & 1 \\
\hline 4901 & NRL & 1 \\
\hline 4919 & ROR1 & NA \\
\hline 494326 & MIR377 & NA \\
\hline 49854 & ZBTB21 & NA \\
\hline 5045 & FURIN & 1 \\
\hline 50804 & MYEF2 & 1 \\
\hline 5081 & PAX7 & NA \\
\hline 50836 & TAS2R8 & NA \\
\hline 50854 & C6orf48 & NA \\
\hline 50940 & PDE11A & 1 \\
\hline 50999 & TMED5 & NA \\
\hline 51019 & WASHC3 & NA \\
\hline 51069 & MRPL2 & 1 \\
\hline 51086 & TNNI3K & 1 \\
\hline 51117 & COQ4 & 1 \\
\hline 51160 & VPS28 & NA \\
\hline
\end{tabular}




\begin{tabular}{|c|c|c|}
\hline 51161 & C3orf18 & NA \\
\hline 51188 & SS18L2 & NA \\
\hline 51191 & HERC5 & 1 \\
\hline 51334 & PRR16 & 1 \\
\hline 51373 & MRPS17 & NA \\
\hline 51409 & HEMK1 & 1 \\
\hline 51430 & SUCO & NA \\
\hline 5158 & PDE6B & 1 \\
\hline 5159 & PDGFRB & NA \\
\hline 51593 & SRRT & NA \\
\hline 51701 & NLK & 1 \\
\hline 5217 & PFN2 & 1 \\
\hline 523 & ATP6V1A & 1 \\
\hline 5295 & PIK3R1 & 1 \\
\hline 53343 & NUDT9 & NA \\
\hline 5356 & PLRG1 & NA \\
\hline 5359 & PLSCR1 & NA \\
\hline 5365 & PLXNB3 & 1 \\
\hline 54434 & SSH1 & 1 \\
\hline 54487 & DGCR8 & 1 \\
\hline 54502 & RBM47 & 1 \\
\hline 54503 & ZDHHC13 & NA \\
\hline 54758 & KLHDC4 & 1 \\
\hline 54795 & TRPM4 & 1 \\
\hline 54811 & ZNF562 & NA \\
\hline 54897 & CASZ1 & 1 \\
\hline 54940 & OCIAD1 & NA \\
\hline 55033 & FKBP14 & NA \\
\hline 55036 & CCDC40 & 1 \\
\hline 55062 & WIPI1 & 1 \\
\hline 55068 & ENOX1 & 1 \\
\hline 55088 & CCDC186 & NA \\
\hline 55114 & ARHGAP17 & 1 \\
\hline 55127 & HEATR1 & NA \\
\hline 55159 & RFWD3 & NA \\
\hline 55160 & ARHGEF10L & 1 \\
\hline 55276 & PGM2 & 1 \\
\hline 55283 & MCOLN3 & NA \\
\hline 553103 & MIR3936HG & 1 \\
\hline 55315 & SLC29A3 & NA \\
\hline
\end{tabular}




\begin{tabular}{|c|c|c|c|}
\hline 55336 & FBXL8 & 1 & 1 \\
\hline 55361 & $\mathrm{PI} 4 \mathrm{~K} 2 \mathrm{~A}$ & 1 & 1 \\
\hline 55532 & SLC30A10 & 1 & NA \\
\hline 55611 & OTUB1 & NA & 1 \\
\hline 5562 & PRKAA1 & NA & 1 \\
\hline 55635 & DEPDC1 & 1 & 1 \\
\hline 5575 & PRKAR1B & 1 & NA \\
\hline 55758 & RCOR3 & 1 & NA \\
\hline 55790 & CSGALNACT1 & NA & 1 \\
\hline 55819 & RNF130 & 1 & 1 \\
\hline 55854 & ZC3H15 & NA & 1 \\
\hline 55902 & ACSS2 & 1 & 1 \\
\hline 55924 & FAM212B & 1 & NA \\
\hline 56005 & MYDGF & 1 & 1 \\
\hline 56134 & PCDHAC2 & 1 & 1 \\
\hline 56135 & PCDHAC1 & 1 & NA \\
\hline 56136 & PCDHA13 & 1 & NA \\
\hline 56137 & PCDHA12 & 1 & NA \\
\hline 56138 & PCDHA11 & 1 & NA \\
\hline 56139 & PCDHA10 & 1 & NA \\
\hline 56140 & PCDHA8 & 1 & NA \\
\hline 56141 & PCDHA7 & 1 & NA \\
\hline 56142 & PCDHA6 & 1 & NA \\
\hline 56143 & PCDHA5 & 1 & NA \\
\hline 56144 & PCDHA4 & 1 & NA \\
\hline 56145 & PCDHA3 & 1 & NA \\
\hline 56146 & PCDHA2 & 1 & NA \\
\hline 56147 & PCDHA1 & 1 & NA \\
\hline 56474 & CTPS2 & NA & 1 \\
\hline 56704 & JPH1 & NA & 1 \\
\hline 56853 & CELF4 & 1 & NA \\
\hline 5687 & PSMA6 & NA & 1 \\
\hline 56886 & UGGT1 & 1 & 1 \\
\hline 56937 & PMEPA1 & 1 & NA \\
\hline 56950 & SMYD2 & 1 & NA \\
\hline 57030 & SLC17A7 & 1 & 1 \\
\hline 57132 & CHMP1B & 1 & 1 \\
\hline 57150 & SMIM8 & 1 & NA \\
\hline 57209 & ZNF248 & 1 & NA \\
\hline 57337 & SENP7 & NA & 1 \\
\hline
\end{tabular}




\begin{tabular}{|c|c|c|c|}
\hline 57348 & TTYH1 & 1 & NA \\
\hline 57379 & AICDA & 1 & NA \\
\hline 574481 & MIR521-2 & NA & 1 \\
\hline 57474 & ZNF490 & 1 & NA \\
\hline 57513 & CASKIN2 & 1 & NA \\
\hline 57536 & KIAA1328 & NA & 1 \\
\hline 57544 & TXNDC16 & NA & 1 \\
\hline 57553 & MICAL3 & 1 & NA \\
\hline 57556 & SEMA6A & NA & 1 \\
\hline 57569 & ARHGAP20 & 1 & 1 \\
\hline 57575 & PCDH10 & NA & 1 \\
\hline 57582 & KCNT1 & 1 & NA \\
\hline 57620 & STIM2 & 1 & NA \\
\hline 57654 & UVSSA & 1 & NA \\
\hline 57666 & FBRSL1 & 1 & NA \\
\hline 57693 & ZNF317 & 1 & NA \\
\hline 57758 & SCUBE2 & NA & 1 \\
\hline 5789 & PTPRD & 1 & NA \\
\hline 5793 & PTPRG & 1 & NA \\
\hline 5816 & PVALB & 1 & 1 \\
\hline 583 & BBS2 & NA & 1 \\
\hline 5832 & ALDH18A1 & 1 & 1 \\
\hline 5977 & DPF2 & NA & 1 \\
\hline 5990 & RFX2 & 1 & NA \\
\hline 5993 & RFX5 & NA & 1 \\
\hline 6095 & RORA & 1 & NA \\
\hline 619343 & NA & 1 & NA \\
\hline 6262 & RYR2 & 1 & NA \\
\hline 63027 & SLC22A23 & NA & 1 \\
\hline 6329 & SCN4A & NA & 1 \\
\hline 639 & PRDM1 & NA & 1 \\
\hline 63976 & PRDM16 & 1 & NA \\
\hline 642366 & LOC642366 & 1 & NA \\
\hline 64328 & XPO4 & 1 & 1 \\
\hline 64377 & CHST8 & 1 & NA \\
\hline 643803 & KRTAP24-1 & 1 & NA \\
\hline 64478 & CSMD1 & 1 & NA \\
\hline 646903 & LOC646903 & NA & 1 \\
\hline 64746 & ACBD3 & NA & 1 \\
\hline 64786 & TBC1D15 & NA & \\
\hline
\end{tabular}




\begin{tabular}{|c|c|c|}
\hline 64853 & AIDA & NA \\
\hline 64881 & PCDH20 & 1 \\
\hline 64919 & BCL11B & NA \\
\hline 6497 & SKI & 1 \\
\hline 65012 & SLC26A10 & NA \\
\hline 65108 & MARCKSL1 & NA \\
\hline 6514 & SLC2A2 & NA \\
\hline 652276 & LOC652276 & NA \\
\hline 6584 & SLC22A5 & NA \\
\hline 6585 & SLIT1 & NA \\
\hline 6588 & SLN & NA \\
\hline 65985 & AACS & 1 \\
\hline 65996 & CENPBD1P1 & 1 \\
\hline 66005 & CHID1 & NA \\
\hline 6604 & SMARCD3 & 1 \\
\hline 6631 & SNRPC & 1 \\
\hline 6648 & SOD2 & 1 \\
\hline 6687 & SPG7 & 1 \\
\hline 6788 & STK3 & 1 \\
\hline 6865 & TACR2 & 1 \\
\hline 6867 & TACC1 & 1 \\
\hline 6892 & TAPBP & NA \\
\hline 6904 & TBCD & 1 \\
\hline 693220 & MIR635 & NA \\
\hline 699 & BUB1 & 1 \\
\hline 7003 & TEAD1 & 1 \\
\hline 7020 & TFAP2A & 1 \\
\hline 7025 & NR2F1 & 1 \\
\hline 7068 & THRB & 1 \\
\hline 7077 & TIMP2 & 1 \\
\hline 715 & C1R & 1 \\
\hline 7164 & TPD52L1 & 1 \\
\hline 7226 & TRPM2 & 1 \\
\hline 7262 & PHLDA2 & NA \\
\hline 7277 & TUBA4A & 1 \\
\hline 728192 & LINC00460 & 1 \\
\hline 728912 & NA & 1 \\
\hline 728932 & NA & 1 \\
\hline 728939 & NA & 1 \\
\hline 7323 & UBE2D3 & 1 \\
\hline
\end{tabular}




\begin{tabular}{|c|c|c|c|}
\hline 7342 & UBP1 & 1 & 1 \\
\hline 7444 & VRK2 & 1 & NA \\
\hline 747 & DAGLA & NA & 1 \\
\hline 7520 & XRCC5 & 1 & NA \\
\hline 768 & CA9 & 1 & NA \\
\hline 773 & CACNA1A & 1 & NA \\
\hline 7771 & ZNF112 & NA & 1 \\
\hline 78988 & MRPL57 & NA & 1 \\
\hline 79018 & GID4 & 1 & NA \\
\hline 79087 & ALG12 & NA & 1 \\
\hline 7915 & ALDH5A1 & 1 & NA \\
\hline 79174 & CRELD2 & 1 & 1 \\
\hline 79696 & $\mathrm{ZC} 2 \mathrm{HC} 1 \mathrm{C}$ & NA & 1 \\
\hline 79703 & C11orf80 & 1 & NA \\
\hline 79745 & CLIP4 & 1 & 1 \\
\hline 79791 & FBX031 & 1 & NA \\
\hline 79812 & MMRN2 & 1 & NA \\
\hline 79832 & QSER1 & 1 & NA \\
\hline 79890 & RIN3 & NA & 1 \\
\hline 79896 & THNSL1 & NA & 1 \\
\hline 79913 & ACTR5 & 1 & NA \\
\hline 79918 & SETD6 & 1 & NA \\
\hline 79919 & C2orf54 & 1 & NA \\
\hline 79960 & JADE1 & 1 & NA \\
\hline 79977 & GRHL2 & 1 & NA \\
\hline 80005 & DOCK5 & 1 & NA \\
\hline 8001 & GLRA3 & NA & 1 \\
\hline 80086 & TUBA4B & NA & 1 \\
\hline 80125 & CCDC33 & 1 & NA \\
\hline 80176 & SPSB1 & 1 & NA \\
\hline 8021 & NUP214 & 1 & NA \\
\hline 80218 & NAA50 & NA & 1 \\
\hline 8022 & LHX3 & 1 & NA \\
\hline 80312 & TET1 & 1 & NA \\
\hline 80728 & ARHGAP39 & NA & 1 \\
\hline 80760 & ITIH5 & 1 & 1 \\
\hline 81029 & WNT5B & 1 & NA \\
\hline 81532 & MOB2 & 1 & NA \\
\hline 8174 & MADCAM1 & 1 & NA \\
\hline 8310 & ACOX3 & 1 & 1 \\
\hline
\end{tabular}




\begin{tabular}{|c|c|c|}
\hline 83538 & TTC25 & NA \\
\hline 83659 & TEKT1 & NA \\
\hline 8369 & HIST1H4G & 1 \\
\hline 8372 & HYAL3 & 1 \\
\hline 83943 & IMMP2L & 1 \\
\hline 84033 & OBSCN & 1 \\
\hline 84056 & KATNAL1 & 1 \\
\hline 84067 & FAM160A2 & NA \\
\hline 84068 & SLC10A7 & NA \\
\hline 84080 & ENKD1 & 1 \\
\hline 84126 & ATRIP & 1 \\
\hline 84166 & NLRC5 & 1 \\
\hline 84236 & RHBDD1 & 1 \\
\hline 84264 & HAGHL & 1 \\
\hline 84272 & YIPF4 & NA \\
\hline 84284 & NTPCR & NA \\
\hline 84302 & TMEM246 & NA \\
\hline 84316 & NAA38 & NA \\
\hline 84435 & ADGRA1 & NA \\
\hline 8460 & TPST1 & NA \\
\hline 8470 & SORBS2 & 1 \\
\hline 84725 & PLEKHA8 & 1 \\
\hline 84856 & LINC00839 & 1 \\
\hline 84858 & ZNF503 & NA \\
\hline 84929 & FIBCD1 & 1 \\
\hline 8495 & PPFIBP2 & 1 \\
\hline 85001 & MGC16275 & 1 \\
\hline 8532 & CPZ & 1 \\
\hline 8536 & CAMK1 & NA \\
\hline 85403 & EAF 1 & NA \\
\hline 857 & CAV1 & 1 \\
\hline 8601 & RGS20 & 1 \\
\hline 864 & RUNX3 & 1 \\
\hline 8661 & EIF3A & 1 \\
\hline 8664 & EIF3D & NA \\
\hline 8677 & STX10 & NA \\
\hline 8717 & TRADD & NA \\
\hline 8736 & MYOM1 & 1 \\
\hline 8775 & NAPA & NA \\
\hline 8835 & SOCS2 & 1 \\
\hline
\end{tabular}




\begin{tabular}{|c|c|c|}
\hline 8927 & BSN & NA \\
\hline 894 & CCND2 & NA \\
\hline 8943 & AP3D1 & NA \\
\hline 89953 & KLC4 & 1 \\
\hline 90025 & UBE3D & 1 \\
\hline 902 & $\mathrm{CCNH}$ & NA \\
\hline 90427 & BMF & 1 \\
\hline 90525 & SHF & 1 \\
\hline 9117 & SEC22C & 1 \\
\hline 91408 & BTF3L4 & 1 \\
\hline 9141 & PDCD5 & NA \\
\hline 91452 & ACBD5 & 1 \\
\hline 91603 & ZNF830 & NA \\
\hline 91748 & ELMSAN1 & 1 \\
\hline 91750 & LIN52 & NA \\
\hline 91775 & NXPE3 & 1 \\
\hline 92345 & NAF1 & 1 \\
\hline 9249 & DHRS3 & 1 \\
\hline 92521 & SPECC1 & 1 \\
\hline 928 & CD9 & 1 \\
\hline 9364 & RAB28 & NA \\
\hline 93974 & ATP5IF1 & 1 \\
\hline 94015 & TTYH2 & NA \\
\hline 9423 & NTN1 & 1 \\
\hline 9440 & MED17 & NA \\
\hline 9443 & MED7 & NA \\
\hline 9538 & EI24 & 1 \\
\hline 9570 & GOSR2 & 1 \\
\hline 9578 & CDC42BPB & 1 \\
\hline 9592 & IER2 & 1 \\
\hline 960 & CD44 & 1 \\
\hline 9644 & SH3PXD2A & 1 \\
\hline 9692 & KIAA0391 & 1 \\
\hline 9703 & KIAA0100 & 1 \\
\hline 9718 & ECE2 & 1 \\
\hline 9747 & TCAF1 & 1 \\
\hline 9752 & PCDHA9 & 1 \\
\hline 9759 & HDAC4 & 1 \\
\hline 9761 & MLEC & 1 \\
\hline 9913 & SUPT7L & 1 \\
\hline
\end{tabular}


bioRxiv preprint doi: https://doi.org/10.1101/422345; this version posted November 1 2018. The copyright holder for this preprint (which was not certified by peer review) is the author/funder, who has granted bioRxiv a license to display the preprint in perpetuity. It is made available under aCC-BY-NC-ND 4.0 International license.

\begin{tabular}{llcc}
9924 & PAN2 & 1 & NA \\
9941 & EXOG & 1 & 1 \\
9986 & RCE1 & NA & 1 \\
\hline
\end{tabular}


Supplemental Table 4. Overlap of MD related DMPs and DMRs with PGC GWAS loci.

\begin{tabular}{ccccc}
\hline Chromosome & DNAm.start & DNAm.end & PGC.start & PGC.end \\
\hline chr6 & 29521506 & 29521506 & 27738000 & 32848000 \\
chr6 & 30031455 & 30031455 & 27738000 & 32848000 \\
chr6 & 30519905 & 30521619 & 27738000 & 32848000 \\
chr6 & 31828260 & 31830030 & 27738000 & 32848000 \\
chr6 & 32797253 & 32798887 & 27738000 & 32848000 \\
chr10 & 106401479 & 106401479 & 106397000 & 106904000 \\
\hline
\end{tabular}


Supplemental Table 5. Overlap of MD related VMPs and VMRs with PGC GWAS loci.

\begin{tabular}{ccccc}
\hline Chromosome & DNAm.start & DNAm.end & PGC.start & PGC.end \\
\hline chr2 & 58265673 & 58265673 & 57765000 & 58485000 \\
chr5 & 164658718 & 164658718 & 164440000 & 164789000 \\
chr6 & 28706472 & 28706472 & 27738000 & 32848000 \\
chr6 & 28890673 & 28890673 & 27738000 & 32848000 \\
chr6 & 31324972 & 31324972 & 27738000 & 32848000 \\
chr6 & 31707922 & 31707922 & 27738000 & 32848000 \\
chr6 & 31802397 & 31802397 & 27738000 & 32848000 \\
chr6 & 32049516 & 32049825 & 27738000 & 32848000 \\
chr6 & 32055738 & 32055738 & 27738000 & 32848000 \\
chr6 & 32789916 & 32789916 & 27738000 & 32848000 \\
chr6 & 32818212 & 32818212 & 27738000 & 32848000 \\
chr6 & 32847830 & 32847830 & 27738000 & 32848000 \\
\hline
\end{tabular}

